Copyright (C) 2019 by the author(s). Published here under license by the Resilience Alliance.

Sitas, N., Z. V. Harmáčková, J. A. Anticamara, A. Arneth, R. Badola, R. Biggs, R. Blanchard, L. Brotons, M. Cantele, K. Coetzer, R. DasGupta, E. Den Belder, S. Ghosh, A. Guisan, H. Gundimeda, M. Hamann, P. A. Harrison, S. Hashimoto, J. Hauck, B. Klatt, K. Kok, R. M. Krug, A. Niamir, P. J. O'Farrell, S. Okayasu, I. Palomo, L. M. Pereira, P. Riordan, F. Santos-Martín, O. Selomane, Y. Shin, and M. Valle Tobar. 2019. Exploring the usefulness of scenario archetypes in science-policy processes: experience across IPBES assessments. Ecology and Society 24(3):35. https://doi.org/10.5751/ES-11039-240335

Research, part of a Special Feature on Archetype Analysis in Sustainability Research

\title{
Exploring the usefulness of scenario archetypes in science-policy processes: experience across IPBES assessments
}

\author{
$\underline{\text { Nadia Sitas }}^{1,2,3}, \underline{\text { Zuzana V. Harmáčková }}{ }^{4,5}, \underline{\text { Jonathan A. Anticamara }}^{6}, \underline{\text { Almut Arneth }}^{7}, \underline{\text { Ruchi Badola }}^{8}, \underline{\text { Reinette Biggs }}^{1,4}, \underline{\text { Ryan }}$ \\ Blanchard $^{13,9}$, Lluis Brotons $^{10,11,12}$, Matthew Cantele ${ }^{13,14}$, Kaera Coetzer ${ }^{15}$, Rajarshi Das Gupta ${ }^{16}$, Eefje den Belder ${ }^{17}$, Sonali Ghosh ${ }^{18}$,

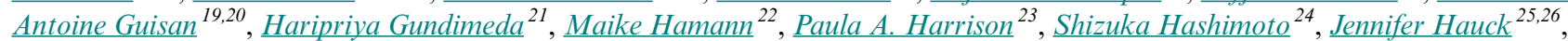

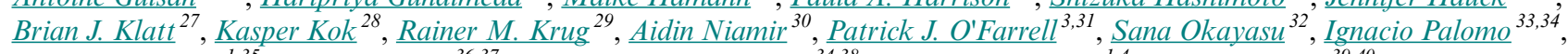 \\ $\underline{\text { Laura M. Pereira }}^{1,35}, \underline{\text { Philip Riordan }}^{36,37}$. Fernando Santos-Martín $^{34,38}$, Odirilwe Selomane $^{1,4}$, Yunne-Jai Shin $^{39,40}$ and Mireia Valle $^{33,41}$
}

\begin{abstract}
Scenario analyses have been used in multiple science-policy assessments to better understand complex plausible futures. Scenario archetype approaches are based on the fact that many future scenarios have similar underlying storylines, assumptions, and trends in drivers of change, which allows for grouping of scenarios into typologies, or archetypes, facilitating comparisons between a large range of studies. The use of scenario archetypes in environmental assessments foregrounds important policy questions and can be used to codesign interventions tackling future sustainability issues. Recently, scenario archetypes were used in four regional assessments and one ongoing global assessment within the Intergovernmental Science-Policy Platform for Biodiversity and Ecosystem Services (IPBES). The aim of these assessments was to provide decision makers with policy-relevant knowledge about the state of biodiversity, ecosystems, and the contributions they provide to people. This paper reflects on the usefulness of the scenario archetype approach within science-policy processes, drawing on the experience from the IPBES assessments. Using a thematic analysis of (a) survey data collected from experts involved in the archetype analyses across IPBES assessments, (b) notes from IPBES workshops, and (c) regional assessment chapter texts, we synthesize the benefits, challenges, and frontiers of applying the scenario archetype approach in a science-policy process. Scenario archetypes were perceived to allow syntheses of large amounts of information for scientific, practice-, and policy-related purposes, streamline key messages from multiple scenario studies, and facilitate communication of them to end users. In terms of challenges, they were perceived as subjective in their interpretation, oversimplifying information, having a limited applicability across scales, and concealing contextual information and novel narratives. Finally, our results highlight what methodologies, applications, and frontiers in archetype-based research should be explored in the future. These advances can assist the design of future large-scale sustainability-related assessment processes, aiming to better support decisions and interventions for equitable and sustainable futures.
\end{abstract}

Key Words: assessment; biodiversity; decision making; ecosystem services; futures; nature; regional; scenarios

\section{INTRODUCTION}

The world is rapidly changing and bold decisions are required to transform societies toward more equitable and sustainable development pathways (MA 2005, Butchart et al. 2010, Pereira et al. 2010, Kull et al. 2015, Steffen et al. 2015). Assessments, at local to global scales, are an important mechanism for synthesizing current information to inform policy and decision making. This involves analyzing impacts of the status quo, exploring potential future changes, as well as identifying interventions that can lead to desired outcomes (e.g., MA 2005, IPCC 2014). Such information is especially relevant in light of the United Nations 2030 Agenda for Sustainable Development

\footnotetext{
${ }^{1}$ Centre for Complex Systems in Transition, Stellenbosch University, South Africa, ${ }^{2}$ Department of Conservation Ecology, Stellenbosch University, South Africa, ${ }^{3}$ Council for Scientific and Industrial Research, South Africa, ${ }^{4}$ Stockholm Resilience Centre, Stockholm University, Sweden, ${ }^{5}$ Bolin Centre for Climate Research, Stockholm University, Sweden, ${ }^{6}$ UP Diliman Invertebrate Museum - Institute of Biology, National Science Complex, University of the Philippines-Diliman, Quezon City, Philippines, ${ }^{7}$ KIT, Department of Atmospheric Environmental Research, GarmischPartenkirchen, Germany, ${ }^{8}$ Wildlife Institute of India, Dehradun, India, ${ }^{9}$ Centre for Invasion Biology, Stellenbosch University, South Africa, ${ }^{10}$ CREAF, Barcelona, Spain, ${ }^{11}$ InForest Jru (CTFC-CREAF), Solsona, Spain, ${ }^{12}$ CSIC, Cerdanyola del Vallés, Spain, ${ }^{13}$ International Institute for Applied Systems Analysis, Laxenburg, Austria, ${ }^{14}$ School of BioSciences, University of Melbourne, Parkville, Victoria, Australia, ${ }^{15}$ Global Change Institute, University of the Witwatersrand, Johannesburg, South Africa, ${ }^{16}$ Institute for Global Environmental Strategies, Hayama, Kanagawa, Japan, ${ }^{17}$ Agrosystems, Wageningen University \& Research, Wageningen, the Netherlands, ${ }^{18}$ Ministry of Environment, Forests \& Climate Change, India, ${ }^{19}$ Department of Ecology and Evolution, University of Lausanne, Lausanne, Switzerland, ${ }^{20}$ Institute of Earth Surface Dynamics, University of Lausanne, Lausanne, Switzerland, ${ }^{21}$ Department of Humanities and Social Sciences, Indian Institute of Technology Bombay, Powai, Mumbai, India, ${ }^{22}$ Humphrey School of Public Affairs, University of Minnesota, Minneapolis, Minnesota, USA, ${ }^{23}$ Centre for Ecology \& Hydrology, Lancaster Environment Centre, Bailrigg, Lancaster, UK, ${ }^{24}$ Department of Ecosystem Studies, The University of Tokyo, Japan, ${ }^{25}$ CoKnow Consulting, Jesewitz, Germany, ${ }^{26}$ Helmholtz Centre for Environmental Research - UFZ, Leipzig, Germany, ${ }^{27}$ Michigan State University, East Lansing, Michigan, USA, ${ }^{28}$ Wageningen University \& Research, Wageningen, the Netherlands, ${ }^{29}$ University of Zurich, Department of Evolutionary Biology and Environmental Studies, Zurich, Switzerland, ${ }^{30}$ Senckenberg Biodiversity and Climate Research Institute, Germany, ${ }^{31}$ Percy FitzPatrick Institute of African Ornithology, University of Cape Town, Rondebosch, South Africa, ${ }^{32}$ PBL Netherlands Environmental Assessment Agency, ${ }^{33}$ Basque Centre for Climate Change (BC3), Leioa, Spain, ${ }^{34}$ Social-Ecological Systems Laboratory, Department of Ecology, Universidad Autónoma de Madrid, Spain, ${ }^{35}$ Centre for Food Policy, City University of London, UK, ${ }^{36}$ Marwell Wildlife, UK, ${ }^{37}$ University of Southampton, UK, ${ }^{38}$ Departamento ESCET, Universidad Rey Juan Carlos de Madrid, Spain fernando.santos@urjc.es, ${ }^{39}$ MARBEC, Institut de Recherche pour le Développement (IRD), IFREMER, CNRS, Univ Montpellier, France, ${ }^{40}$ University of Cape Town, Department of Biological Sciences, Marine Research Institute (Ma-Re), South Africa, ${ }^{41}$ National Center for Ecological Analysis and Synthesis, Santa Barbara, California, USA
} 
(UN General Assembly 2015) and associated Sustainable Development Goals (SDGs), Aichi Biodiversity Targets (CBD 2010), and other policy platforms striving to achieve a broad range of integrated social, economic, and environmental targets into the future.

\section{Box 1:}

Scenario development and analysis have been widely used in a number of different fields of research such as industry, military, business, and science (Raskin et al. 2002, Börjeson et al. 2006, Kok et al. 2011). Scenarios have also been used in a number of environmental assessment processes at different scales, such as the Global Biodiversity Outlook (GBO), Intergovernmental Panel for Climate Change (IPCC), Millennium Ecosystem Assessment (MA), and Global Environmental Outlook (GEO), in order to understand the impacts of global change on a variety of issues including biodiversity loss, the contributions of nature to people, as well as good quality of life. Scenarios can be developed through numerous approaches (Peterson et al. 2003, Carpenter et al. 2006, IPBES 2016), including participatory approaches (Bohensky et al. 2011, Oteros-Rozas et al. 2015, Richards et al. 2017), as well as stakeholders' values, norms, and desirability of particular outcomes (Kok et al. 2011).

To connect science to policy, scenarios can be classified as "exploratory," "intervention," or "policy evaluation" (IPBES 2016). Exploratory scenarios evaluate a range of plausible futures based on potential trajectories of drivers, both indirect (e.g., economic, socio-political, and technical) and direct (e.g., climate change, land-use change), and are also often used for awareness raising purposes and to stimulate creative thinking (Kok et al. 2011). Intervention scenarios evaluate alternative policy or management options through either target seeking or policy screening analyses, while policy evaluation scenarios assess the extent to which policy interventions match expected modeled projections (van Vuuren et al. 2012, IPBES 2016).

Understanding the complex interactions between social and ecological components of systems and their implications for future development is challenging given inherent uncertainties (Cash et al. 2006, Ostrom 2009). Scenarios, defined broadly as plausible stories about how the future might unfold, provide a useful means to understand the dynamics underpinning different potential trajectories of future development. Thus, scenarios deal with future uncertainty and can help decision makers to design policies and actions addressing the impacts of global and local change (Peterson et al. 2003, Biggs et al. 2007, Carpenter et al. 2009, IPBES 2016; see Box 1 for more details). However, there is currently a plethora of scenarios in the literature, which hampers their usefulness for decision makers (Harrison et al. 2019).

The approach of archetype analysis, defined as a "comparative approach that seeks to identify recurrent patterns among cases" (Eisenack et al. 2006, 2019) can assist with harmonizing available research and enhance its relevance for decision makers (Oberlack et al. 2019). Although in this paper, the archetype approach was specifically applied to develop a "typology of cases" of future scenarios (Oberlack et al. 2019), archetypes have been used in multiple contexts and have proven to be a useful approach to address sustainability-related issues (Oberlack et al. 2019). For instance, archetype analyses have been used to explore the diversity of patterns related to environmental degradation (Sietz et al. 2006), vulnerability (Sietz et al. 2011, 2017, Kok et al. 2016, Oberlack et al. 2016, Vidal Merino et al. 2019), land system types (Václavík et al. 2013), teleconnections (Fragkias et al. 2017), or to explore different future pathways (Luederitz et al. 2017).

Consequently, scenario archetype approaches have been widely applied to group scenarios into typologies based on their similar inner scenario logic, underpinning storylines and characteristics (Gallopin et al. 1997, Hunt et al. 2012, van Vuuren et al. 2012; Pedde et al. 2019). These typologies or categories of scenarios have been denoted in the literature as "scenario families" or "scenario archetypes" (Hunt et al. 2012, Harrison et al. 2019). The archetype approach for categorizing scenarios allows policy makers to place their particular situations within a broader context, encouraging connections to be made between regional and global issues and exploring possible solutions (Eisenack et al. 2006, UNEP 2007).

An archetype approach to harmonize future scenarios was recently implemented in the assessments by the Intergovernmental Science-Policy Platform on Biodiversity and Ecosystem Services (IPBES), an intergovernmental body of researchers, practitioners, and decision makers, established by its member states in 2012 (see Box 2).

The IPBES assessments reviewed available future scenarios to explore how nature (including biodiversity), nature's contributions to people (including ecosystem services), and their contributions to good quality of life (including human well-being) might change over time under different conditions (see also IPBES 2016). All Chapters 5 of the IPBES regional assessments-Africa, Americas, Asia-Pacific, and Europe and Central Asia-aligned existing scenario analyses from within their respective regions with previously published archetypes as an approach to assess plausible futures for each region (https://www.ipbes.net/ deliverables/2b-regional-assessments; Biggs et al. 2018, Gundimeda et al. 2018, Harrison et al. 2018, Klatt et al. 2018), with the assumption that this would enable comparability of findings across regions. Using an archetype approach was also proposed as a way to integrate regional findings within the IPBES global assessment.

\section{Box 2:}

The Intergovernmental Science-Policy Platform for Biodiversity and Ecosystem Services (IPBES; Larigauderie and Mooney 2010, Díaz et al. 2015) is an independent intergovernmental body, established by member states in 2012 with the goal of providing policy makers with scientific assessments on the state of knowledge on biodiversity, ecosystems, and the contributions they provide to people. This knowledge includes peer-reviewed publications as well as indigenous and local knowledge. The most recent outputs include four regional assessments (for Africa, Americas, Asia-Pacific, and Europe and Central Asia; IPBES $2018 a, 2018 b, 2018 c, 2018 d$ ) and the land degradation and restoration assessment (IPBES 2018e), approved by the IPBES 6 Plenary in March 2018. These will be followed by a global assessment on nature, its contributions to people and their quality of life, which was approved in May 2019. All regional assessment 
reports share a common structure of 6 chapters, in which Chapter 5 focuses on the future scenarios of human-nature interactions. The author teams of each chapter consist of an interdisciplinary group of regional experts, nominated either by governments or by organizations, and selected by the IPBES Multidisciplinary Expert Panel. These experts volunteered their time and expertise to perform a review and assessment of existing studies that explore the future state of biodiversity and/or ecosystem services and human well-being under different scenarios in their region of interest. As is the case for all IPBES assessments, the aim was to assess current knowledge, and not to create new scenarios. These "regional reviews" were synthesized and presented in the regional assessment reports (available at https://www.ipbes.net/deliverables/2bregional-assessments).

Given that many other global, regional, or thematic environmental assessments may continue to use scenario archetype approaches in their analyses, there is a need for a reflection of the benefits and potential challenges or barriers in the current use of scenario archetypes within science-policy processes to help guide future applications and elaborate on the lessons learned through the IPBES regional assessments. Based on the current application of scenario archetypes in the IPBES work program, notably the regional assessments, our aim in this paper is to explore the perceived benefits, challenges, and future opportunities of using such an approach for communicating and operationalizing scientific findings in policy and decision making. This aim is implemented by a mixed method approach primarily based on surveying interdisciplinary researchers' perceptions involved in the scenario archetype analyses in IPBES assessments. Furthermore, we highlight the ways in which the use of a scenario archetype approach can advance understanding of what additional methodologies, applications, and frontiers in scenario research still need to be pursued.

\section{METHODS}

This study used a qualitative, mixed method approach to explore three key data sources: (1) the text of the individual scenario chapters in four completed IPBES regional assessments (Biggs et al. 2018, Gundimeda et al. 2018, Harrison et al. 2018, Klatt et al. 2018) and the draft of the scenario chapters of the IPBES global assessment; (2) the notes from various IPBES related workshops; and (3) a survey among the experts involved in the scenario archetype analyses in the regional assessments. This approach allowed us to compare the outcomes of the scenario archetype analysis across regional assessments as well as to reflect on the application of the scenario archetype approach in IPBES and the lessons learned. It is important to note that the results in this paper do not represent the opinions of the authors, but are based on the text of the chapters, meeting notes, and experts' opinions elicited through the survey. A more detailed account of our method can be found as supplementary information in Appendix 1.

\section{Comparative analysis of IPBES regional assessments}

A comparative analysis of the scenario chapters from each of the regional assessments was carried out to explore what specific approaches were used for each of the scenario archetype analyses. The screening of the text focused on (a) the reported purpose of applying the scenario archetype approach, (b) the set of scenario archetypes used, and (c) specific steps taken to conduct the archetype analysis in the chapters.

\section{Meeting notes from IPBES workshops}

We consolidated all meeting and workshop notes linked to the IPBES regional assessments where the archetype approach was discussed and assessed the content of the meeting notes using the same assessment framework outlined above to determine the rationale for using an archetype approach. The resulting information supplemented the survey question on the process and decision to use scenario archetypes.

\section{Survey among IPBES experts}

The reflections of how the scenario archetype approach was applied in respective regional assessments were elicited from experts involved in the IPBES assessments through an online survey. The survey was sent out to respondents purposively sampled based on their involvement with either (a) The scenario chapter (Chapter 5) of one of the regional assessments, (b) members of the IPBES Scenarios and Models assessment (IPBES 2016) and the Technical Support Unit on Scenarios and Models, and (c) authors involved in ongoing archetype-based work in the IPBES global assessment. All coordinating lead authors and fellows of the regional assessment scenario chapters were invited and requested to suggest additional respondents, e.g., selected lead and contributing authors, involved in the scenario archetype analyses in the assessment. A total of 30 respondents completed the online survey (70\% response rate; Fig. 1; see also Appendix 2 for respondents' profile). In addition to the survey questions, respondents were asked what role they have played, or experience they have, in science-policy processes to determine to what extent they can comment on the usefulness of scenario archetypes for science-policy processes (Appendix 2).

The survey contained a series of open- and close-ended questions (Appendix 1), first eliciting the profile of the survey participants, and second, focusing on the perceptions of the use of scenario archetypes in their respective regional assessments. The responses highlighted multiple topics, which were subsequently grouped under the following themes: the process that led to the use of the scenario archetype approach and its perceived purpose, perceived benefits and challenges of using scenario archetypes in the regional assessments, research frontiers related to the scenario archetype approach, and links to policy and decision making through addressing policy priorities. The responses to the survey were subsequently collated and analyzed to derive a set of themes for each of the key questions reflected in this paper.

The survey was administered by the colead authors of this paper, and the respondents were invited to comment on the manuscript and become its coauthors. Thus, there was a partial overlap between the respondents of the survey and the coauthors of the present paper. However, the coleads of this paper were responsible for the analysis of the results and effort was made to ensure that the paper conveys solely the reflections captured formally through the survey, and not personal opinions to ensure independence of the data and the narrative.

\section{Data analysis}

We analyzed our data using a combination of deductive and inductive content analysis (Fereday and Muir-Cochrane 2006). First, all data (from the comparative analysis of assessment 
Fig. 1. Involvement of respondents in individual Intergovernmental Science-Policy Platform for Biodiversity and Ecosystem Services (IPBES) assessments and groups $(\mathrm{n}=30)$. Some respondents reported multiple roles within IPBES, therefore the counts add up to more than 30.

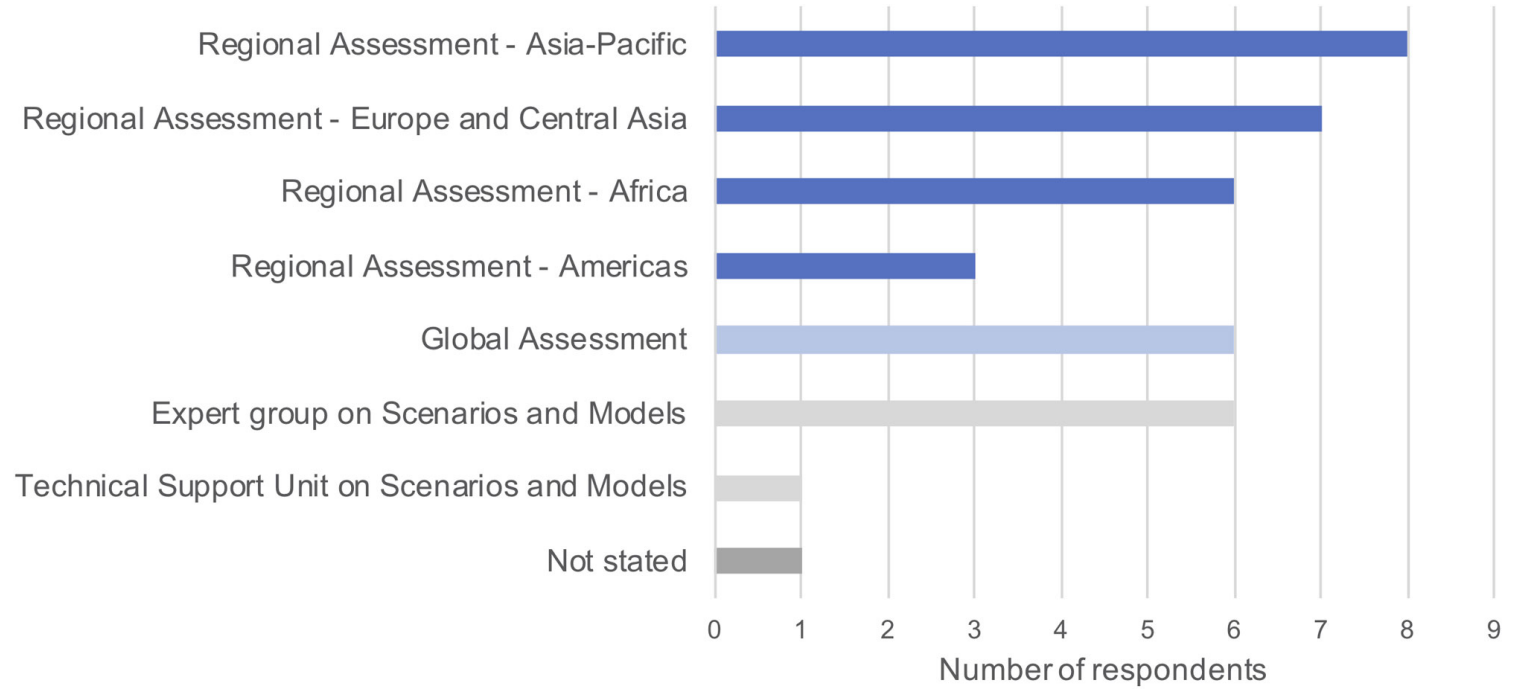

chapters, meeting notes, and survey responses) were analyzed to see whether any themes emerged. This resulted in topics emerging linked to (a) the approaches that were used; (b) themes that linked to identified difficulties, challenges, barriers, or obstacles (which we then grouped under "challenges") or themes that were linked to enabling contexts, benefits, or opportunities (which we grouped as "benefits"), and (c) any topics that linked to potential research frontiers. The survey specifically asked about the weaknesses, barriers, or challenges associated with the use of scenario archetypes, which we then clustered under the theme "challenges," and the strengths which we clustered under "benefits."

\section{RESULTS AND DISCUSSION}

\section{Regional approaches for scenario archetype assessment}

All regional assessments used a scenario archetype approach to synthesize a variety of published future scenarios for the different regions. The respondents indicated that scenario archetypes served multiple purposes within the regional assessments, including (a) a synthesizing function, (b) a way to link between sections and themes within chapters, (c) an opportunity to link between chapters of each regional assessment, for example, between the scenarios chapter and the chapter on policy or governance options, and (d) a potential link and means of comparison between different regional assessments and the global assessment.

In terms of methodological steps, all regional assessments first selected a pre-existing set of global archetypes (Hunt et al. 2012, van Vuuren et al. 2012, IPBES 2016), which slightly differed, but mostly corresponded to those identified by the Global Scenario Group (Gallopin et al. 1997; Table 1 and A3.1). Each assessment used four to six scenario archetypes. Second, individual future scenarios identified through regional reviews were compared, matched, or classified to these archetypes (Biggs et al. 2018, Gundimeda et al. 2018, Harrison et al. 2018, Klatt et al. 2018).
Third, each region adjusted the selection and titles of the archetypes based on regional context and the detailed evidence from the reviewed scenarios. Despite this third step, the resulting sets of scenario archetypes largely corresponded, and several archetypes were represented across all regional assessments (as highlighted in Table A3.1). Each of the IPBES regional assessments further analyzed the scenario archetypes differently and to various extents (for a brief overview, see Table 2; further details are provided in Appendix 3). For example, both the Africa and Europe and Central Asia assessments adjusted and further developed the global archetypes to create regionally specific versions, based on information from the respective regional reviews (Biggs et al. 2018, Harrison et al. 2018, Harrison et al. 2019), whereas the Americas and Asia-Pacific assessments did not.

Chapter 4 of the global assessment (IPBES 2015a; at the stage of the Second Order Draft) used scenario archetypes primarily to organize reviewed global scenarios, addressing changes in biodiversity and ecosystems, nature's contributions to people, and good quality of life. Subsequently, selected trends related to nature and nature's contributions to people, e.g., selected types of ecosystem services, were analyzed per archetype.

\section{Benefits of the use of scenario archetypes}

We found that the use of scenario archetypes was perceived to be especially beneficial in synthesizing large amounts of diverse scenario-based information to increase policy relevance. This is the expected outcome of large-scale assessments: to critically evaluate and synthesize existing evidence for the purposes of guiding decisions on complex public policy issues (Watson 2012) and thus bridge the science-policy gap (Bradshaw and Borchers 2000, Larigauderie and Mooney 2010, Koetz et al. 2012, Livoreil et al. 2016). 
Table 1. Overview of the original set of global archetypes and their underlying assumptions that were used as a starting point to classify scenarios within the Intergovernmental Science-Policy Platform for Biodiversity and Ecosystem Services (IPBES) regional assessments. The first column contains attributes typically used to describe scenario archetypes. Economic optimism scenarios focus on competition, efficient market, and economic growth; reformed market scenarios are similar to economic optimism but corrected for market failures; global sustainable development scenarios focus on environmental protection and reduction of inequality through global cooperation, lifestyle change using efficient technologies; regional competition scenarios feature regional self-reliance, national sovereignty and regional identity but also involve tensions with other regions; regional sustainability scenarios highlight globalization and international markets that are seen to erode traditional values and social norms; and finally business-as-usual scenarios that assume continuation of historical trends (Van Vuuren et al 2012, IPBES 2016). These were rationalized in the IPBES regional assessment (Biggs et al. 2018, Gundimeda et al. 2018, Harrison et al. 2018, Klatt et al. 2018.)

\begin{tabular}{|c|c|c|c|c|c|c|}
\hline \multirow[t]{2}{*}{ Attribute } & \multicolumn{6}{|c|}{ Scenario Archetype } \\
\hline & $\begin{array}{l}\text { Economic } \\
\text { optimism }\end{array}$ & Reformed markets & $\begin{array}{l}\text { Global sustainable } \\
\text { development }\end{array}$ & $\begin{array}{l}\text { Regional } \\
\text { sustainability }\end{array}$ & $\begin{array}{l}\text { Regional } \\
\text { competition }\end{array}$ & Business-as-usual \\
\hline Economic development & Very rapid & Rapid & $\begin{array}{l}\text { Ranging from } \\
\text { slow to rapid }\end{array}$ & Medium & Slow & Medium \\
\hline Population growth & Low & Low & Low & Medium & High & Medium \\
\hline Technology development & Rapid & Rapid & $\begin{array}{l}\text { Ranging from } \\
\text { medium to rapid }\end{array}$ & Medium to rapid & Slow & Medium \\
\hline $\begin{array}{l}\text { Environmental technology } \\
\text { development }\end{array}$ & Rapid & Rapid & Rapid & $\begin{array}{l}\text { Ranging from } \\
\text { slow to rapid }\end{array}$ & Slow & Medium \\
\hline Main objectives & Economic growth & Various goals & $\begin{array}{l}\text { Global } \\
\text { sustainability }\end{array}$ & $\begin{array}{l}\text { Local } \\
\text { sustainability }\end{array}$ & Security & Not defined \\
\hline Environmental protection & Reactive & $\begin{array}{l}\text { Both reactive and } \\
\text { proactive }\end{array}$ & Proactive & Proactive & Reactive & $\begin{array}{l}\text { Both reactive and } \\
\text { proactive }\end{array}$ \\
\hline Trade & Globalization & Globalization & Globalization & Trade barriers & Trade barriers & Weak globalization \\
\hline Policies and institutions & $\begin{array}{l}\text { Policies create } \\
\text { open markets }\end{array}$ & $\begin{array}{l}\text { Policies targeted at } \\
\text { market failures }\end{array}$ & $\begin{array}{l}\text { Strong global } \\
\text { governance }\end{array}$ & Local actors & $\begin{array}{l}\text { Strong national } \\
\text { governments }\end{array}$ & Mixed \\
\hline Vulnerability to climate change & Medium-high & Low & Low & Possibly low & Mixed & Medium \\
\hline
\end{tabular}

Relevance of scenario archetypes for policy and decision making An additional important perceived benefit of scenario archetypes for policy and decision making was that they facilitate policy makers' understanding of how decisions taken at different scales, e.g., regional trade agreements or global climate agreements, can impact nature in different ways at another scale (see also Liu et al. 2013 on telecoupling, which highlights socioeconomic and environmental interactions over distances and scales).

The experts in the survey also emphasized the benefits of scenario archetypes for communication and attention raising, as well as triggering discussion on potential consequences of decisions and action pathways. Scenarios in general have been highlighted as useful "boundary objects" within sustainability research and practice, i.e., objects understood slightly differently in different communities and disciplines, but robust enough to be used by all, and thus serve as a mediator across worlds and enabling joint work (Garb et al. 2008, Mollinga 2010, White et al. 2010), echoing our findings that many respondents found scenario archetypes to be useful communication and translation tools, facilitating engagement around complex topics or sustainability challenges (Sterner et al. 2019).

In addition, general benefits were highlighted that are usually attributed to scenarios more broadly, such as envisioning diverse plausible futures, exploring potential pathways, and highlighting policy options, addressing uncertainty and thus increasing robustness of decisions (IPBES 2016).

\section{Benefits of scenario archetypes as a scientific approach}

The scenario archetype approach was recognized by many as a useful common analytical framework to assess and synthesize numerous diverse scenarios (e.g., originating from different spatial scales and geographic regions), clarify their commonalities, and thus productively build on existing scenario work. Consequently, scenario archetypes were seen as a tool to upscale local, national, and subregional scenarios to explore plausible regional futures. Scenario archetypes were suggested simultaneously to address a range of policy-relevant themes, rarely captured together by individual scenarios, such as trends in drivers of change and their effects on biodiversity, ecosystem services, and human well-being, as well as the ability to achieve future policy targets.

\section{Challenges of using scenario archetypes}

\section{Challenges of applying scenario archetypes in a science-policy process}

In terms of challenges specific to the application of scenario archetypes within IPBES, the respondents identified several process and method-related challenges, which may serve as a learning example for future science-policy processes (see Appendix 4 for further details on the process of adopting scenario archetypes in IPBES).

In terms of the process, although one of the key original motivations for undertaking a scenario archetype approach in the regional assessments was to facilitate cross-regional comparisons of scenario archetypes, this was not fulfilled within the regional assessments and may not be possible in the global assessment because of three decision-process related issues. First, some of the regional assessments had already selected certain scenario archetype sets before inter-regional coordination meetings, and thus the resulting sets of scenario archetypes differed between the 
Table 2. Table outlining the different purposes, archetype approach, and subsequent analyses taken by each of the Intergovernmental Science-Policy Platform for Biodiversity and Ecosystem Services (IPBES) regional assessments (Africa, Americas, Asia Pacific, and Europe and Central Asia), outlined in more detail in the full reports (Biggs et al. 2018, Gundimeda et al. 2018, Harrison et al. 2018, Klatt et al. 2018; available online at: https://www.ipbes.net/deliverables/2b-regional-assessments).

\begin{tabular}{|c|c|c|c|}
\hline Region & Purpose of using scenario archetypes & Archetype approach applied & Analysis \\
\hline Africa & $\begin{array}{l}\text { To explore the implications of different } \\
\text { possible evolving relationships between } \\
\text { nature and society, particularly in terms of } \\
\text { key drivers of change and impacts on } \\
\text { biodiversity, Nature's Contributions for } \\
\text { People (NCP; "biodiversity and ecosystem } \\
\text { services"), human well-being, poverty, and } \\
\text { inequality ("human well-being } \\
\text { outcomes"), while highlighting the } \\
\text { potential implications for the Sustainable }\end{array}$ & $\begin{array}{l}\text { Selection of underlying scenarios: } 6 \text { core studies } \\
\text { (containing } 26 \text { scenario storylines) - WWF Ecological } \\
\text { Futures report (WWF-AfDB 2015), GEO-6 regional } \\
\text { asssessment for Africa (UNEP 2016), GEO-4 global } \\
\text { assessment (MA 2005, IPCC 2007, 2014, UNEP } \\
2007 \text { ). } \\
\text { Process: Classification of scenarios into five Global } \\
\text { Scenarios Group (GSG) archetypes (some renamed, } \\
\text { Breakdown omitted from the original set of six). }\end{array}$ & $\begin{array}{l}\text { Assessment of the future trajectories of key } \\
\text { drivers, biodiversity and ecosystem services, } \\
\text { human well-being outcomes, likelihood of } \\
\text { achieving targets, and policy implications } \\
\text { under each of the five archetypes, based on } \\
\text { the comparison of trends in the six core } \\
\text { studies; where possible, supplemented with } \\
\text { studies from the wider set of scenario } \\
\text { studies identified in the systematic review. }\end{array}$ \\
\hline
\end{tabular}

potential implications for the Sustainable Development Goals, Aichi targets, and African Union agenda, as well as priority issues such as climate change and the food-water-energy nexus.

Americas (1) To integrate the IPBES conceptual framework's components, e.g. nature, nature's contributions to people, good quality of life, by examining the relationships between them in the Americas for different biomes; (2) To examine what the future state of biodiversity and NCP may be under different plausible future conditions, i.e., "scenarios";

(3) To discuss the establishment of a framework, or pathway, to inform the policy process to attain a sustainable future.

Asia- To provide comprehensive assessment of

Pacific the available scenarios on current and future interactions between nature, nature's contributions to people, and good quality of life within the Asia-Pacific region, in particular:

(1) To evaluate the trends and trajectories of these interactions;

(2) To provide insights on the pathways fo sustainability of nature, nature's contributions to people and good quality of life;

(3) To lead to further exploration of policy options.

Europe To synthesize:

and (1) Future changes in indirect and direct

Central drivers of biodiversity, ecosystem, and

Asia ecosystem services change;

(2) Potential future impacts of these drivers on nature, its contributions to people, and a good quality of life; (3) The consistency of multiple pathways for sustainable development with the scenario archetypes from the perspective of Sustainable Development Goals and Aichi Biodiversity Targets.
Breakdown omitted from the original set of six).

Most scenarios have already been previously classified into the GSG archetypes in published research literature. Each (global and regional) scenario archetype summarized, briefly described, and assessed for Africa.

Selection of underlying scenarios: Scenario archetypes have been used in a broad sense to discuss different potential trajectories of selected focal issues (presented for biomes).

Process: Prediction outcomes from the Global Biodiversity Model for policy support (GLOBIO) were presented for the following scenarios pathways within the Great Transition scenario archetype: (1) Global Technology, (2) Decentralized Solutions, and (3) Consumption Change.

Selection of underlying scenarios: A total of 204 scenario narratives, derived from 61 reviewed articles were examined and classified into defined archetypes (Hunt et al. 2012) to explore the tentative future pathways as portrayed in regional scenario exercises.

Process: A wide variety of storylines have been depicted in the regional scenario exercises, of which, about $65 \%$ of the storylines were drafted as per researcher's own consideration and not following any of the known development trajectories. Hence, storylines or alternative assumptions found during the literature review were clustered against three major narratives and six general scenario families suggested by Hunt et al. (2012).

Selection of underlying scenarios: 143 exploratory scenario studies (including 436 scenarios) as well as 37 integrated impact modeling studies identified through a systematic review.

Process:

(1) Scenarios screened for their storylines, underlying logic, and assumptions, as well as the qualitative and quantitative values of scenario attributes;

(2) Based on these characteristics, scenarios matched and classified into a preselected set of six global scenario archetypes, out of which five were taken from the IPBES Scenarios and Models assessment (originally based on scenario families described by van Vuuren et al. 2012) and one archetype added (Inequality, see O'Neill et al. 2017). The matching process was assisted by a previously published classification of scenarios into archetypes (Hunt et al. 2012).
Narratives of plausible futures have been presented for some of the described biomes.

Outcomes from the different pathways toward sustainability showed that future prospects to ensure biodiversity and NCP conservation requires rethinking the current orientation from common policies; and that change in societal options could lead to less pressure to nature and help moving toward a sustainable future.

Analysis of potential future impacts on nature, nature's contributions to people and good quality of life, and illustrating their link to selected Sustainable Development Goals concerned with natural ecosystems and Aichi Biodiversity Targets. Discussion of the lack of studies addressing the link to human, economic, and social development.

(1) Development of a regionally specific version of the scenario archetypes developed for Europe and Central Asia and supplemented by detailed information from the reviewed studies (Harrison et al. 2018, 2019).

(2) Summary of future trends in drivers of biodiversity and ecosystem services change, and impacts on nature, its contributions to people, and a good quality of life under different scenario archetypes;

(3) Extent to which Sustainable

Development Goals and Aichi Biodiversity Targets may be reached under the different scenario archetypes.

(4) Overview of subregional impacts consistent across scenario archetypes. 
regional assessments (Appendix 3). Second, the analyses of resulting scenario archetypes undertaken in each regional assessment substantially differed (Table 2), which can be attributed to authors' variable time availability and capacity. Third, the decision to compare across regions was only taken once the regional assessment process had already started, limiting the time and resources available for a more consistent approach and cross-regional comparisons. As a result, the final regionalized scenario archetypes and the depth of their analyses differed to such an extent that it did not allow for cross-regional comparison or synthesis at the global level. Instead, the global assessment (at the stage of Second Order Draft) has opted to use the van Vuuren et al. (2012) scenario archetypes to categorize scenarios originating solely from global-scale studies, without drawing from the regionalized versions of scenario archetypes created on the level of regional assessments.

These results illustrate that in the future, similar processes of implementing a common synthesizing approach across assessments may benefit from clearer and more timely coordination between the assessments (although many respondents agreed that these issues are to a certain extent inherent in this kind of global endeavor acknowledging the limited time, money, and resources available to conduct the assessments). This highlights the importance of a well-resourced, transparently designed assessment approach from the outset, where regional and global assessments can streamline their approaches in order for them to be able to synthesize results across scales, while maintaining sufficient freedom to make their own decisions about the use of scenarios in their assessments. In the future, assessments that aim to undertake cross-regional comparisons should build coordination efforts into their assessment timeline, and allocate the necessary resources to this task, given that most assessment teams consist of expert volunteers (see Balvanera et al. 2017), especially in terms of capacitated teams that have experience in working with relevant methodologies.

In terms of the scenario-archetype methodology adopted in IPBES, a key challenge that was raised was that the classification of scenarios, which often have a qualitative emphasis, into archetypes was based on expert opinion, although guided by previously published classifications (e.g., Hunt et al. 2012). Furthermore, the preselection of scenario archetypes and subsequent classification of scenarios into them in some instances required "forcing" a scenario into an archetype regardless of fit, or the omission of scenarios that did not fit the applied archetype classification from further analyses. In some regions, the number of available scenario studies was found to be insufficient for a meaningful archetype analysis. Another concern was that the set of archetypes selected for IPBES regional assessments was too conventional and biased toward "Western" views, which might stem from the fact that influential sets of scenarios, such as IPCC special reports on emission scenarios (Nakićenović et al. 2000), also originate from this context and have a similar bias. Finally, the resulting regional scenario archetypes were in some cases perceived as suppressing innovative and creative features or narratives from the underlying local-level scenarios as well as ignoring unique or novel approaches taken in their development.

Even though respondents highlighted some challenges associated with using archetypes, it is unclear whether these challenges translate into difficulties for end-users and the policy-relevant use of archetypes as a tool facilitating communication and awareness raising. Evidence from the IPBES regional assessment external review process has shown that while certain IPBES national focal points find the approach useful and have requested specific presentations on the results of the scenario archetype analyses, others have indicated the need for further explanation of the approach.

Challenges of scenario archetypes as a scientific approach The respondents largely agreed with five general challenges of the scenario archetype approach listed in the survey (Fig. 2), namely the following issues:

Fig. 2. Perceived challenges related to the application of scenario archetypes.

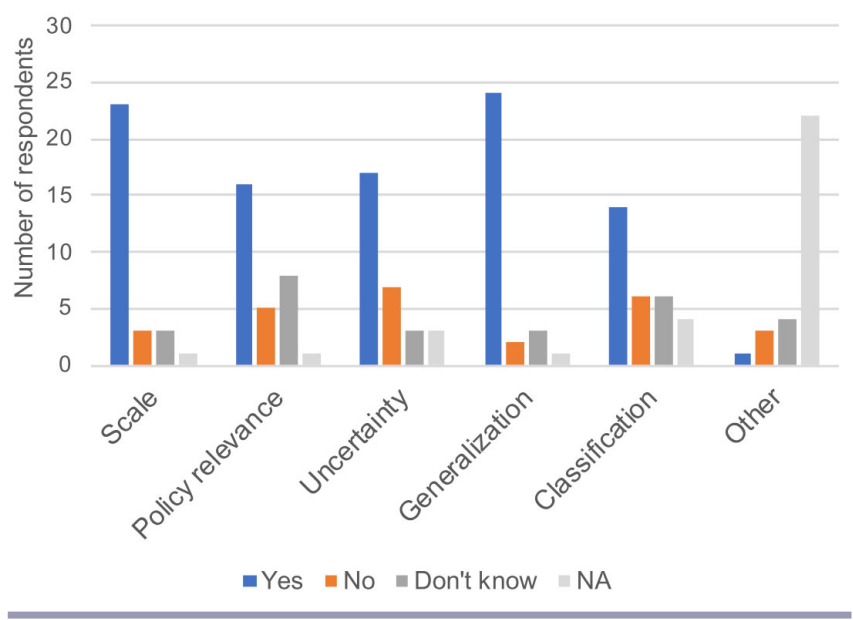

- Generalization of phenomena from individual scenarios: referring to the loss of detail from individual scenarios during the process of harmonization into archetypes, as well as the fact that the sets of archetypes used as a starting point for classification might not have covered all the available scenarios (Curry and Schultz 2009, Boschetti et al. 2016);

- Scale: referring to the mismatches between the spatial and temporal scales at which scenario archetypes are developed and at which policy decisions are made;

- Policy relevance: referring to the practical applicability of scenario archetypes in policy and decision making;

- Amplification of uncertainty: referring to the increase in epistemic uncertainty by combining the uncertainties of the underlying scenarios into archetypes;

- Classification into archetypes: referring to the issues of assigning individual scenarios to different archetypes.

For further details and examples of the identified challenges of the scenario archetype approach, see Table 3 . These challenges were recognized as an inherent characteristic of the scenario archetype approach, not related to its specific application within IPBES. According to the respondents, when communicated transparently to the end-users, these challenges do not fundamentally hamper the potential of scenario archetypes to raise awareness and structure reflections about the future and support decision-making processes. 
Table 3. Summary of challenges of the scenario archetype approach, identified by a survey among Intergovernmental Science-Policy Platform for Biodiversity and Ecosystem Services (IPBES) experts.

\begin{tabular}{ll}
\hline \hline General theme & Specific examples \\
\hline $\begin{array}{l}\text { Generalization of } \\
\text { phenomena from }\end{array}$ & Oversimplifying the evidence in the process of harmonizing scenarios to archetypes, leading to the loss of information from \\
individual scenarios & individual scenarios, unique scenario features, and contextual nuances \\
Comparing cases that are fundamentally different
\end{tabular}

Scale

Limited representativeness of global scenario archetypes for regional dynamics

Constrained ability of large-scale scenario archetypes to sufficiently recognize the impact of local dynamics and to link bottom-up and top-down agency

Loss of cross-scale interaction aspects originally addressed by the underlying scenarios

Policy relevance, $\quad$ Lack of identified leverage points for action in large-scale scenario archetypes, especially concerning a wide range of direct representation of actions, drivers, such as resource extraction, pollution, global warming. The interactions between these drivers are not yet well and action pathways quantified, and are not necessarily represented in either models of impacts, nor in scenario archetypes that are more focused on indirect drivers of change

Insufficient ability of scenario archetypes to differentiate potential impacts for diverse societal groups, e.g., based on inequality linked to gender or wealth, and thus failing to address the justice and equity dimensions

Classification into archetypes

Missing methods to capture the level to which a scenario fits into a scenario archetype (the uncertainty of allocation of a scenario into a specific archetype)

Biases

Geographic biases: limited ability of scenario archetypes to address the diversity of regional and local contexts, e.g., failing to address the importance of governance capacity issues and the influence of external markets in Africa

Temporal biases: limited ability of scenario archetypes to address the temporal variation of the underlying scenarios

\section{Realizing the potential of archetypes as inter-and} transdisciplinary tools

The use of scenario archetypes has been highlighted as a transdisciplinary challenge (Eisenack et al. 2006, 2019). We found that most of the respondents in our survey come from selfidentified natural science or interdisciplinary backgrounds; there was limited expertise from the social sciences, and one from the humanities, policy, or practice domain (Appendix 2). This could in part be due to the nature of the IPBES expert nomination process (IPBES 2018f), which might emphasize the role of scientists serving as experts over indigenous and local knowledge holders, but presents a window of opportunity for change in future IPBES assessment calls (Larigauderie et al. 2016). A lack of inter- and transdisciplinary engagement is a clear gap in terms of strengthening the knowledge base required not only to assess future changes in nature-society relationships, but also in the codevelopment of future scenario archetypes that might reflect the new combinations of drivers of change characterizing in the Anthropocene (Verburg et al. 2016, Kok et al. 2017). However robustly scenario archetypes are developed in scientific terms, how they are subsequently used in practice is often not assessed, with few to no studies reporting on their impact on decisionmaking processes. This is a key gap and could exist either because the development of scenario archetypes has been undertaken within the research domain, without legitimate engagement with the end-users of the results, or that no studies have been conducted that seek to assess how scenario archetypes have impacted policy and practice on the ground.

\section{Research frontiers}

Frontiers of applying scenario archetypes in a science-policy process

In the IPBES regional assessments, the type and depth of scenario archetype analyses undertaken, as well as the breadth of the underlying regional scenario reviews, were limited by time and capacity constraints, e.g., the number of regional assessment experts available. Several types of more detailed analyses have been suggested for potential future science-policy assessments applying the scenario archetype approach:

- Identifying more scenarios in the literature and classifying them into archetypes to identify the most represented, under-represented, or missing archetypes;

- Exploring in greater detail the assumptions of scenarios classified into each archetype;

- Identifying unique features that set regional scenario archetypes apart from existing global or other regional archetypes, e.g., exploring differences between archetypes from the global North versus global South, or differences in impacts on nature, its contributions to people and their quality of life in distinct biomes;

- Developing and exploring new regional scenario archetypes instead of building on existing global ones (such as in the case of IPBES regional assessments);

- Linking scenario archetypes to specific action pathways that are identified by regional policy priorities (e.g., SDGs or climate targets), multiple types of values held by different actors, and normative scenarios;

- Using archetypes to further align findings across chapters within the science-policy assessment process, as well as with other assessments.

Frontiers of scenario archetypes as a scientific approach Frontiers of the scenario archetype approach identified by the respondents were often related to the perceived challenges. The 
Table 4. Summary of research frontiers of the scenario archetype approach, identified by a survey among Intergovernmental SciencePolicy Platform for Biodiversity and Ecosystem Services (IPBES) experts.

\begin{tabular}{ll}
\hline \hline General theme & Specific examples \\
\hline Scale & $\begin{array}{l}\text { Exploring cross-scale linkages and interactions within scenario archetypes, e.g., analyzing the impact of global-scale drivers } \\
\text { on local contexts and at the same time, illustrating how bottom-up activities influence regional- and global-scale processes } \\
\text { Incorporating the specific role of telecoupling (that is, how connections between nature and humans are coupled in a more } \\
\text { globalized world irrespective of some of the large distances between systems) from underlying scenarios in resulting } \\
\text { scenario archetypes }\end{array}$
\end{tabular}

Policy relevance, $\quad$ Linking scenario archetypes to specific policy actions and their consequences

representation of actions Highlighting the action pathways leading to sustainable outcomes under different archetypes, e.g., more normative and action pathways, outcomes like the Sustainable Development Goals and climate or Aichi targets

operationalization of Analyzing synergies and trade-offs between different archetypal policy and action pathways

scenario archetypes for Analyzing internal feedbacks within the scenario storyline, which drive scenario archetype storylines forward, and practice and decision identifying the intervention points at which the direction of the storyline could be changed making

Exploring whether it is possible to construct "archetypical" action pathways and to what extent it is reasonable to link them to scenario archetypes

Biases $\quad$ Geographic biases:

Developing regionally specific versions of scenario archetypes to address regional heterogeneity and recognize local dynamics

Thematic biases:

Including the under-representation of social aspects in scenario archetypes

Considering equity and the implications of archetypes for different groups of people, e.g., based on gender, wealth, urbanrural gradient, size of a community

Emphasizing "non-Western" worldviews in new archetypes

Broadening scenario archetypes beyond their currently prevailing scope, i.e., the assessment of impacts on nature and ecosystem services, and evaluate their implications for human well-being and quality of life

Creating a new generation of scenario archetypes

Participatory approaches in scenario archetype development

Methodological frontiers Quantifying trends and impacts within scenario archetypes

Downscaling global scenario archetypes to regions

Developing structured methods to classify scenario narratives into archetypes

Incorporating the assessment of underlying scenario assumptions in the archetype building

Assessing uncertainty propagation from scenarios to scenario archetypes to impacts.

archetypical options within the sustainability transitions pathway

Utilizing participatory approaches in building scenario archetypes

Involving stakeholders in the translation of global scenario archetypes to regional levels to enhance operationalization
Societal relevance of scenario archetypes
Bridging positive elements from multiple archetypes and finding synergies beyond the archetype boundary

Coproduction of knowledge or knowledge weaving with practitioners and policy makers in terms of participatory scenarios

Exploring the added value of participatory scenario-archetype development for capacity building and empowerment among participants

Monitoring the impact of scenarios and scenario archetypes to improve social-ecological systems management most commonly raised frontiers (see Table 4 for details and examples) were the ability to do the following:

- Address multiple aspects of cross-scale and cross-sectoral interactions in scenario archetypes;

- Link scenario archetypes to specific global and regional policies such as the SDGs or biodiversity or climate targets and associated action pathways;

- Address geographic and thematic biases in archetypes;

- Supplement well-established archetypal narratives (e.g., business-as-usual, collapse, and sustainability transition) with novel ones when developing scenario archetypes;
- Involve diverse stakeholders through participatory approaches when developing scenario archetypes from underlying scenarios;

- Explore methodological advances;

- Enhance the societal relevance of scenario archetypes.

Some of the frontiers repeatedly emerged in combinations, such as the call for the development of archetypes that acknowledge cross-scale interactions in a more participatory and inclusive way.

Frontiers of scenario research underlying scenario archetypes The respondents highlighted that in order to enhance the usefulness of scenario archetypes for policy and decision-making processes, they need to embrace the more nuanced, innovative, and creative details and narratives from local-level studies. This 
was identified as a challenge not related just to scenario archetypes, but to scenarios more broadly.

As a potential solution, the respondents highlighted the need to codevelop methodologies that build bottom-up, multiscale scenarios that link to global scenarios. This was highlighted as a key research frontier by multiple respondents that has also been highlighted by both Kok et al. (2017) and Rosa et al. (2017), in relation to future scenario development for IPBES assessments. Because development activities are implemented at the local level, there is a need to be aligned with local socio-political contextual factors, while at the same time accounting for regional and global structures and dynamics. However, linking scenarios across scales might not always be worthwhile (Kok et al. 2007) and could have negative unintended consequences if local political contexts are not taken into account (Biggs et al. 2007). Linking bottom-up and top-down scenario approaches is challenging (Carpenter et al. 2009) although some approaches have been explored to resolve the methodological and scale-mismatch issues through loosely linking the scenarios (Biggs et al. 2007, van Vuuren et al. 2012) and harmonizing activities, as in the UNEP GEO6 outlooks process (Pereira et al. 2019, UNEP 2019).

Accordingly, the codevelopment of bottom-up scenarios with potential end-users of the results requires in-depth participatory processes that need to be policy-relevant, regionally appropriate, and collaboratively developed through legitimate processes that mobilize diverse knowledge and value systems (Cash et al. 2003, Clark et al. 2016, Kok et al. 2017). Posner et al. (2016) further highlight that at times, issues related to legitimacy may be more important than the perceived credibility of the work. This indicates that extra time could be taken to facilitate meaningful end-user engagement throughout assessment processes. This is perhaps beyond the scope of current IPBES stakeholder engagement activities that function mainly through formal review processes with some perceived restrictions in terms of who and how stakeholders are involved (Granjou et al. 2013). Researchers involved as experts in the IPBES process have identified this as an important challenge and have already begun work to explore how to bridge issues related to scale and diversity in relation to using scenarios as decision-support tools within future IPBES work (Lundquist et al. 2017) and other global environmental assessments such as GEO6 (Pereira et al. 2019, UNEP 2019).

\section{Linking IPBES scenario archetypes to policy priorities}

All respective scenario chapters of the IPBES regional assessments (Biggs et al. 2018, Gundimeda et al. 2018, Harrison et al. 2018, Klatt et al. 2018) strived to support future uptake of scenario archetypes in policy and decision-making processes by linking them (in different ways) to the Sustainable Development Goals (UN General Assembly 2015). Some of the assessments also included other global thematic targets, e.g., climate or biodiversity-related, and regional policy objectives, e.g., European or African Union, in order to enable end-users to link to the assessments and explore the possibilities of achieving their objectives under different scenario archetypes.

In addition, some regional assessments (e.g., Africa and Europe and Central Asia, in their respective Chapter 6) further explored the link between scenario archetypes and alternative options for governance and decision making across scales and sectors. These chapters provided regionally specific governance options for steering development in more equitable and sustainable trajectories by highlighting the impacts on biodiversity and ecosystem services that certain archetypical futures might include. In addition, some of the regions, e.g., Africa, mapped how these impacts might influence key thematic priorities highlighted in the regional scoping report, e.g., the food-energy-water-livelihood nexus, land degradation and invasive species (IPBES 2015b), which emerged from diverse stakeholder engagement on important issues that Africa might face in the future. These interregional differences are important for understanding the way in which scenarios (and even assessments) are used.

Authors of some of the regional assessments have already been requested by decision-making bodies to present some of the scenario archetype findings, for example at the European Council Working Party on International Environment Issues (https:// www.consilium.europa.eu/en/council-eu/preparatory-bodies/workingparty-international-environment-issues/), the 7th African Ministerial Conference of the Environment (AMCEN) (http:// www.unenvironment.org/events/conference/african-ministerial-conferenceenvironment), and other national departments concerned with environmental affairs. The assessments also provided an important opportunity to create an evidence base for future policy discussions and target setting, such as those aligned with the Convention on Biological Diversity's post-2020 agenda (https:// www.cbd.int/post2020/). This represents an important translation of assessment outcomes into policy-relevant formats that are readily available for end-users to utilize and can avoid misinterpretation of results. At the same time, it remains to be seen whether these attempts to link scenario archetypes to policy outcomes are able to ultimately influence policies and practices because many challenges exist that can hamper efforts to bridge the gap between science, policy, and practice (Briggs 2006) and limited evidence to date as to whether assessments can directly influence policy (Waylen and Young 2014, Young et al. 2014).

Thus, the usefulness of the scenario archetype approach for endusers of assessments in policy and practice needs to be further explored, in addition to the expert-opinion based perspective presented in this contribution. This includes the extent to which scenario archetypes can assist with understanding synergies and trade-offs linked to various decision-making contexts. Such an analysis was done to some degree during the official IPBES review process through solicited comments from stakeholders and during workshops with IPBES national focal points of IPBES Member States, but we believe it warrants a more in-depth and targeted analysis.

\section{CONCLUSIONS}

The approach of archetype analysis has been developed as a means to assist policy and decision-making processes dealing with sustainability issues (Oberlack et al. 2019). Here we have illustrated an application of the scenario archetype approach in a large-scale assessment process within the science-policy interface. Through a survey of experts involved in the scenario archetype analysis in IPBES, and text analysis of the scenario chapters of the IPBES regional assessments, we identified some of the perceived benefits and challenges of using scenario archetypes. In doing so, we highlighted the additional methodologies, applications, and frontiers in scenario archetypebased research that need to be pursued in future assessments. 
Our results indicate that while there are largely perceived benefits of this type of approach, especially for synthesizing and communicating a large amount of information in ways that are relevant to decision makers (Zurek and Henrichs 2007), there are remaining challenges associated with a scenario archetype approach. These are consistent with some broader conceptual and methodological challenges outlined in archetype research (Eisenack et al. 2019, Oberlack et al. 2019, Sietz et al. 2019) as well as scenario research more broadly (Biggs et al. 2007, Boschetti et al. 2016, Kok et al. 2017, Rosa et al. 2017).

If coupled with a collaborative design of future assessments together with stakeholders, the advances illustrated in this paper could inform future large-scale sustainability-related assessment processes and help better support decision makers by highlighting options for interventions to build equitable and sustainable futures.

Responses to this article can be read online at: http://www.ecologyandsociety.org/issues/responses. php/11039

\section{Acknowledgments:}

Nadia Sitas, Ryan Blanchard, and Patrick O'Farrell were supported by SwedBio at Stockholm Resilience Centre funded by the Swedish International Development Cooperation Agency (SIDA). Zuzana Harmáčková and Reinette Biggs were supported by the GRAID programme funded by the Swedish International Development Agency (SIDA). Reinette Biggs was also supported by the South African Research Chairs Initiative (SARChI) (grant 98766) and the Swedish Research Council (grant 621-2014-5137). Eefje den Belder was funded by the Ministry of Agriculture, Nature and Food Quality of the Netherlands. Support to Paula A. Harrison was provided by UK Department of Environment, Food and Rural Affairs and the EU-funded IMPRESSIONS project (Grant Agreement 603416). We would also like to thank our reviewers for their constructive comments in shaping this paper.

\section{LITERATURE CITED}

Balvanera, P., U. Pascual, S. Diaz, L. Dziba, A.-H. P. Richard, and S. M. Subramanian. 2017. Urgent need to strengthen the international commitment to IPBES. Nature Ecology and Evolution 1:0197. https://doi.org/10.1038/s41559-017-0197

Biggs, R., F. Kizito, K. Adjonou, M. T. Ahmed, R. Blanchard, K. Coetzer, C. O. Handa, C. Dickens, M. Hamann, P. O'Farrell, K. Kellner, B. Reyers, F. Matose, K. Omar, J.-F. Sonkoue, T. Terer, M. Vanhove, N. Sitas, B. Abrahams, T. Lazarova, and L. Pereira. 2018. Current and future interactions between nature and society. Pages 297-352 in E. Archer, L. Dziba, K. J. Mulongoy, M. A. Maoela, and M. Walters, editors. IPBES (2018): The IPBES regional assessment report on biodiversity and ecosystem services for Africa. IPBES Secretariat, Bonn, Germany.

Biggs, R., C. Raudsepp-Hearne, C. Atkinson-Palombo, E. Bohensky, E. Boyd, G. Cundill, H. Fox, S. Ingram, K. Kok, S. Spehar, M. Tengö, D. Timmer, and M. Zurek. 2007. Linking futures across scales: a dialog on multiscale scenarios. Ecology and Society 12(1):17. https://doi.org/10.5751/ES-02051-120117
Bohensky, E.L., J. R. A. Butler, and D. Mitchell. 2011. Scenarios for knowledge integration: exploring ecotourism futures in Milne Bay, Papua New Guinea. Journal of Marine Biology 2011:504651. https://doi.org/10.1155/2011/504651

Börjeson, L., M. Höjer, K.-H. Dreborg, T. Ekvall, and G. Finnveden. 2006. Scenario types and techniques: towards a user's guide. Futures 38(7):723-739. https://doi.org/10.1016/j.futures.2005.12.002

Boschetti, F., J. Price, and I. Walker. 2016. Myths of the future and scenario archetypes. Technological Forecasting and Social Change 111:76-85. https://doi.org/10.1016/j.techfore.2016.06.009

Bradshaw, G. A., and J. G. Borchers. 2000. Uncertainty as information: narrowing the science-policy gap. Ecology and Society 4(1):7. https://doi.org/10.5751/ES-00174-040107

Briggs, S. V. 2006. Integrating policy and science in natural resources: why so difficult? Ecological Management and Restoration 7(1):37-39. https://doi.org/10.1111/j.1442-8903.2006.00245. $\underline{\mathrm{X}}$

Brink, B. J. E. ten., M. Cantele, V. M. Adams, A. Bonn, J. Davies, M. Fernández, N. Matthews, J. Morris, W. A. Ramírez Hernández, M. A. Schoolenberg, M. van den Berg, D. Pennock, and D. P. van. Vuuren. 2018. Scenarios of land degradation and restoration. Pages 532-592 in L. Montanarella, R. Scholes, and A. Brainich, editors. IP BES (2018): The IP BES assessment report on land degradation and restoration. IPBES Secretariat, Bonn, Germany.

Butchart, S. H. M., M. Walpole, B. Collen, A. Van Strien, J. P. W. Scharlemann, R. E. A. Almond, J. E. M. Baillie, B. Bomhard, C. Brown, J. Bruno, K. E. Carpenter, G. M. Carr, J. Chanson, A. M. Chenery, J. Csirke, N. C. Davidson, F. Dentener, M. Foster, A. Galli, J. N. Galloway, P. Genovesi, R. D. Gregory, M. Hockings, V. Kapos, J. F. Lamarque, F. Leverington, J. Loh, M. A. McGeoch, L. McRae, A. Minasyan, M. H. Morcillo, T. E. E. Oldfield, D. Pauly, S. Quader, C. Revenga, J. R. Sauer, B. Skolnik, D. Spear, D. Stanwell-Smith, S. N. Stuart, A. Symes, M. Tierney, T. D. Tyrrell, J. C. Vié, and R. Watson. 2010. Global biodiversity: indicators of recent declines. Science 328(5982):1164-1168. https://doi.org/10.1126/science.1187512

Carpenter, S. R., E. M. Bennett, and G. D. Peterson. 2006. Scenarios for ecosystem services: an overview. Ecology and Society 11(1):29. https://doi.org/10.5751/ES-01610-110129

Carpenter, S. R., H. A. Mooney, J. Agard, D. Capistrano, R. S. Defries, S. Díaz, T. Dietz, A. K. Duraiappah, A. Oteng-Yeboah, H. M. Pereira, C. Perrings, W. V. Reid, J. Sarukhan, R. J. Scholes, and A. Whyte. 2009. Science for managing ecosystem services: beyond the Millennium Ecosystem Assessment. Proceedings of the National Academy of Sciences of the United States of America 106(5):1305-1312. https://doi.org/10.1073/pnas.0808772106

Cash, D. W., W. N. Adger, F. Berkes, P. Garden, L. Lebel, P. Olsson, L. Pritchard, and O. Young. 2006. Scale and cross-scale dynamics: governance and information in a multilevel world. Ecology and Society 11(2):8. https://doi.org/10.5751/ES-01759-110208

Cash, D. W., W. C. Clark, F. Alcock, N. M. Dickson, N. Eckley, H. D. Guston, J. Jäger, and R. B. Mitchell. 2003. Knowledge systems for sustainable development. Proceedings of the National Academy of Sciences 100(14):8086-8091. https://doi.org/10.1073/ pnas. 1231332100 
Clark, W. C., L. van Kerkhoff, L. Lebel, and G. C. Gallopin. 2016. Crafting usable knowledge for sustainable development. Proceedings of the National Academy of Sciences 113 (17):4570-4578. https://doi.org/10.1073/pnas.1601266113

Convention on Biological Diversity (CBD). 2010. Decision X/2: The strategic plan for biodiversity 2011-2020 and the Aichi Biodiversity Targets. Secretariat of the Convention on Biological Diversity, Montréal, Québec, Canada.

Curry, A., and W. Schultz. 2009. Roads less travelled: different methods, different futures. Journal of Futures Studies 13(4):35-60.

Díaz, S., S. Demissew, J. Carabias, C. Joly, M. Lonsdale, N. Ash, A. Larigauderie, J. R. Adhikari, S. Arico, A. Báldi, A. Bartuska, I. A. Baste, A. Bilgin, E. Brondizio, K. M. A. Chan, V. E. Figueroa, A. Duraiappah, M. Fischer, R. Hill, T. Koetz, P. Leadley, P. Lyver, G. M. Mace, B. Martin-Lopez, M. Okumura, D. Pacheco, U. Pascual, E. S. Pérez, B. Reyers, E. Roth, O. Saito, R. J. Scholes, N. Sharma, H. Tallis, R. Thaman, R. Watson, T. Yahara, Z. A. Hamid, C. Akosim, Y. Al-Hafedh, R. Allahverdiyev, E. Amankwah, T. S. Asah, Z. Asfaw, G. Bartus, A. L. Brooks, J. Caillaux, G. Dalle, D. Darnaedi, A. Driver, G. Erpul, P. EscobarEyzaguirre, P. Failler, A. M. M. Fouda, B. Fu, H. Gundimeda, S. Hashimoto, F. Homer, S. Lavorel, G. Lichtenstein, W. A. Mala, W. Mandivenyi, P. Matczak, C. Mbizvo, M. Mehrdadi, J. P. Metzger, J. B. Mikissa, H. Moller, H. A. Mooney, P. Mumby, H. Nagendra, C. Nesshover, A. A. Oteng-Yeboah, G. Pataki, M. Roué, J. Rubis, M. Schultz, P. Smith, R. Sumaila, K. Takeuchi, S. Thomas, M. Verma, Y. Yeo-Chang, and D. Zlatanova. 2015. The IPBES conceptual framework: connecting nature and people. Current Opinion in Environmental Sustainability 14:1-16. https:// doi.org/10.1016/j.cosust.2014.11.002

Eisenack, K., M. Lüdeke, and J. Kropp. 2006. Construction of archetypes as a formal method to analyze social-ecological systems. In IDGEC Synthesis Conference of the Institutional Dimensions of Global Environmental Change. Bali, Indonesia, 6-9 December. International Human Dimensions Programme of Global Environmental Change, Bonn, Germany. [online] URL: https:/uol.de/fileadmin/user_upload/wire/fachgebiete/envdev/download/ arch-eisenack3.pdf

Eisenack, K., S. Villamayor-Tomás, G. Epstein, C. Kimmich, N. Magliocca, D. Manuel-Navarrete, C. Oberlack, M. Roggero, and D. Sietz. 2019. Design and quality criteria for archetype analysis. Ecology and Society 24(3):6 https://doi.org/10.5751/ES-10855-240306

Fereday, J., and E. Muir-Cochrane. 2006. Demonstrating rigor using thematic analysis: a hybrid approach of inductive and deductive coding and theme development. International Journal of Qualitative Methods 5(1):80-92. https://doi.org/10.1177/1609$\underline{40690600500107}$

Fragkias, M., S. Islam, and C. Sprague. 2017. Modeling teleconnected urban social-ecological systems: opportunities and challenges for resilience research. International Journal of Urban Sustainable Development 9(2):207-225. https://doi. org/10.1080/19463138.2017.1324455

Gallopin, G. C., A. Hammond, P. Raskin, and R. Swart. 1997. Branch points: global scenarios and human choice. A resource paper of the global scenario group. PoleStar Series Report Number 7. Stockholm Environment Institute, Stockholm, Sweden.
Garb, Y., S. Pulver, and S. D. Vandeveer. 2008. Scenarios in society, society in scenarios: toward a social scientific analysis of storyline-driven environmental modeling. Environmental Research Letters 3(4). https://doi.org/10.1088/1748-9326/3/4/045015

Granjou, C., I. Mauz, S. Louvel, and V. Tournay. 2013. Assessing nature? The genesis of the Intergovernmental Platform on Biodiversity and Ecosystem Services (IPBES). Science, Technology and Society 18(1):9-27. https://doi.org/10.1177/0971$\underline{721813484232}$

Gundimeda, H., P. Riordan, S. Managi, J. A. Anticamara, S. Hashimoto, R. Dasgupta, R. Badola, S. M. Subramanian, H. Yamano, R. Ishii, N. H. Ravindranath, and S. Ghosh. 2018. Chapter 5: Current and future interactions between nature and society. Pages 373-427 in M. Karki, S. Senaratna Sellamuttu, S. Okayasu, and W. Suzuki, editors. IPBES (2018): The IPBES regional assessment report on biodiversity and ecosystem services for Asia and the Pacific. IPBES Secretariat, Bonn, Germany.

Harrison, P. A., Z. V. Harmáčková, A. Aloe Karabulut, L. Brotons, M. Cantele, J. Claudet, R. W. Dunford, A. Guisan, I. P. Holman, S. Jacobs, K. Kok, A. Lobanova, A. Morán-Ordóñez, S. Pedde, C. Rixen, F. Santos-Martín, M. A. Schlaepfer, C. Solidoro, A. Sonrel, and J. Hauck. 2019. Synthesizing plausible futures for biodiversity and ecosystem services in Europe and Central Asia using scenario archetypes. Ecology and Society 24 (2):27. https://doi.org/10.5751/ES-10818-240227

Harrison, P. A., J. Hauck, G. Austrheim, L. Brotons, M. Cantele, J. Claudet, C. Fürst, A. Guisan, Z. V. Harmáčková, S. Lavorel, G. A. Olsson, V. Proença, C. Rixen, F. Santos-Martín, M. Schlaepfer, C. Solidoro, Z. Takenov, and J. Turok. 2018. Current and future interactions between nature and society. Pages 571-660 in M. Rounsevell, M. Fischer, A. Torre-Marin Rando, and A. Mader, editors. IPBES (2018): The IPBES regional assessment report on biodiversity and ecosystem services for Europe and Central Asia. IPBES Secretariat, Bonn, Germany.

Hunt, D. V. L., D. R. Lombardi, S. Atkinson, A. R. G. Barber, M. Barnes, C. T. Boyko, J. Brown, J. Bryson, D. Butler, S. Caputo, M. Caserio, R. Coles, R. F. D. Cooper, R. Farmani, M. Gaterell, J. Hale, C. Hales, C. N. Hewitt, L. Jankovic, I. Jefferson, J. Leach, A. R. MacKenzie, F. A. Memon, J. P. Sadler, C. Weingaertner, J. D. Whyatt, and C. D. F. Rogers. 2012. Scenario archetypes: converging rather than diverging themes. Sustainability 4 (4):740-772. https://doi.org/10.3390/su4040740

Intergovernmental Panel on Climate Change (IPCC). 2007. Climate change 2007: synthesis report. The Fourth Assessment Report of the Intergovernmental Panel on Climate Change. Cambridge University Press, Cambridge, UK.

Intergovernmental Panel on Climate Change (IPCC). 2014. Climate change 2014: synthesis report. Contribution of Working Groups I, II and III to the Fifth Assessment Report of the Intergovernmental Panel on Climate Change. R.K. Pachauri and L.A. Meyer, editors. IPCC, Geneva, Switzerland.

Intergovernmental Science-Policy Platform for Biodiversity and Ecosystem Services (IPBES). 2015a. IPBES/4/8: Scoping report for a global assessment on biodiversity and ecosystem services (deliverable 2 (c)). IPBES Secretariat, Bonn, Germany. 
Intergovernmental Science-Policy Platform for Biodiversity and Ecosystem Services (IPBES). 2015b. IP BES/3/6/Add.2: Report on the regional scoping process for a set of regional and subregional assessments (deliverable 2(b)): Draft complementary scoping report for the regional assessment of biodiversity and ecosystem services for Africa. IPBES Secretariat, Bonn, Germany.

Intergovernmental Science-Policy Platform for Biodiversity and Ecosystem Services (IPBES). 2016. IPBES Methodological assessment report on scenarios and models of biodiversity and ecosystem services. S. Ferrier, K. N. Ninan, P. Leadley, R. Alkemade, L. A. Acosta, H. R. Akçakaya, L. Brotons, W. Cheung, V. Christensen, K. A. Harhash, J. Kabubo-Mariara, C. Lundquist, M. Obersteiner, H. Pereira, G. Peterson, R. PichsMadruga, N. H. Ravindranath, C. Rondinini, and B. Wintle, editors. IPBES Secretariat, Bonn, Germany.

Intergovernmental Science-Policy Platform for Biodiversity and Ecosystem Services (IPBES). 2018a. Summary for policymakers of the regional assessment report on biodiversity and ecosystem services for Africa of the Intergovernmental Science-Policy Platform on Biodiversity and Ecosystem Services. E. Archer, L. E. Dziba, K. J. Mulongoy, M. A. Maoela, M. Walters, R. Biggs, M.C. Cormier-Salem, F. DeClerck, M. C. Diaw, A. E. Dunham, P. Failler, C. Gordon, K. A. Harhash, R. Kasisi, F. Kizito, W. D. Nyingi, N. Oguge, B. Osman-Elasha, L. C. Stringer, L. Tito de Morais, A. Assogbadjo, B. N. Egoh, M. W. Halmy, K. Heubach, A. Mensah, L. Pereira, and N. Sitas, editors. IPBES Secretariat, Bonn, Germany.

Intergovernmental Science-Policy Platform for Biodiversity and Ecosystem Services (IPBES). 2018b. Summary for policymakers of the regional assessment report on biodiversity and ecosystem services for the Americas of the Intergovernmental Science-Policy Platform on Biodiversity and Ecosystem Services. J. Rice, C. S. Seixas, M. E. Zaccagnini, M. Bedoya-Gaitán, N. Valderrama, C. B. Anderson, M. T. K. Arroyo, M. Bustamante, J. Cavender-Bares, A. Díaz-de-León, S. Fennessy, J. R. García Marquez, K. Garcia, E. H. Helmer, B. Herrera, B. Klatt, J. P. Ometo, V. Rodriguez Osuna, F. R. Scarano, S. Schill, and J. S. Farinaci, editors. IPBES Secretariat, Bonn, Germany.

Intergovernmental Science-Policy Platform for Biodiversity and Ecosystem Services (IPBES). 2018c. Summary for policymakers of the regional assessment report on biodiversity and ecosystem services for Asia and the Pacific of the Intergovernmental SciencePolicy Platform on Biodiversity and Ecosystem Services. M. Karki, S. Senaratna Sellamuttu, S. Okayasu, W. Suzuki, L. Acosta, Y. Alhafedh, J. A. Anticamara, A. G. Ausseil, K. Davies, A. Gasparatos, H. Gundimeda, F. H. Ibrahim, R. Kohsaka, R. Kumar, S. Managi, N. Wu, A. Rajvanshi, G. S. Rawat, P. Riordan, S. Sharma, A. Virk, C. Wang, T. Yahara and Y. Youn, editors. IPBES Secretariat, Bonn, Germany.

Intergovernmental Science-Policy Platform for Biodiversity and Ecosystem Services (IPBES). 2018d. Summary for policymakers of the regional assessment report on biodiversity and ecosystem services for Europe and Central Asia of the Intergovernmental Science-Policy Platform on Biodiversity and Ecosystem Services. M. Fischer, M. Rounsevell, A. Torre-Marin Rando, A. Mader, A. Church, M. Elbakidze, V. Elias, T. Hahn. P. A. Harrison, J. Hauck, B. Martín-López, I. Ring, C. Sandström, I. Sousa Pinto, P.
Visconti, N. E. Zimmermann, and M. Christie, editors. IPBES Secretariat, Bonn, Germany.

Intergovernmental Science-Policy Platform for Biodiversity and Ecosystem Services (IPBES). 2018e: Summary for policymakers of the assessment report on land degradation and restoration of the Intergovernmental Science-Policy Platform on Biodiversity and Ecosystem Services. R. Scholes, L. Montanarella, A. Brainich, N. Barger, B. ten Brink, M. Cantele, B. Erasmus, J. Fisher, T. Gardner, T. G. Holland, F. Kohler, J. S. Kotiaho, G. Von Maltitz, G. Nangendo, R. Pandit, J. Parrotta, M. D. Potts, S. Prince, M. Sankaran, and L. Willemen, editors. IPBES Secretariat, Bonn, Germany.

Intergovernmental Science-Policy Platform for Biodiversity and Ecosystem Services (IPBES). 2018f. The IPBES Assessment guide summary. IPBES Secretariat, Bonn, Germany.

Klatt, B. J., J. R. García Márquez., J. P. Ometto, M. Valle, M. E. Mastrangelo, T. Gadda, W. A. Pengue, W. Ramírez Hernández., M. P. Baptiste Espinosa, S. V. Acebey Quiroga, M. V. Blanco, J. Agard, and M. C. Guezala Villavicencio. 2018. Current and future interactions between nature and society. Pages 439-519 in J. Rice, C. S. Seixas, M. E. Zaccagnini, M. Bedoya-Gaitán, and N. Valderrama, editors. IPBES (2018): The IPBES regional assessment report on biodiversity and ecosystem services for the Americas. IPBES Secretariat, Bonn, Germany.

Koetz, T., K. N. Farrell, and P. Bridgewater. 2012. Building better science-policy interfaces for international environmental governance: assessing potential within the Intergovernmental Platform for Biodiversity and Ecosystem Services. International Environmental Agreements: Politics, Law and Economics 12 (1):1-21. https://doi.org/10.1007/s10784-011-9152-Z

Kok, K., R. Biggs, and M. Zurek. 2007. Methods for developing multiscale participatory scenarios: insights from southern Africa and Europe. Ecology and Society 13(1):8. https://doi.org/10.5751/ ES-01971-120108

Kok, K., and S. Pedde. 2016. IMPRESSIONS socio-economic scenarios. EU FP7 IMPRESSIONS Project Deliverable D2.2.

Kok, K., S. Pedde, M. Gramberger, P. A. Harrison, and I. P. Holman. 2019. New European socio-economic scenarios for climate change research: operationalising concepts to extend the shared socio-economic pathways. Regional Environmental Change 19(3):643-654. https://doi.org/10.1007/s10113-018-1400-0

Kok, K., M. van Vliet Mathijs, I. Bärlund, A. Dubel, and J. Sendzimir. 2011. Combining participative backcasting and exploratory scenario development: experiences from the SCENES project. Technological Forecasting and Social Change 78 (5):835-851. https://doi.org/10.1016/j.techfore.2011.01.004

Kok, M., M. Lüdeke, P. Lucas, T. Sterzel, C. Walther, P. Janssen, D. Sietz, and I. de Soysa. 2016. A new method for analysing socioecological patterns of vulnerability. Regional Environmental Change 16(1):229-243. https://doi.org/10.1007/s10113-014-0746-1

Kok, M. T. J., K. Kok, G. D. Peterson, R. Hill, J. Agard, and S. R. Carpenter. 2017. Biodiversity and ecosystem services require IPBES to take novel approach to scenarios. Sustainability Science 12(1):177-181. https://doi.org/10.1007/s11625-016-0354-8 
Kull, C. A., X. A. de Sartre, and M. Castro-Larrañaga. 2015. The political ecology of ecosystem services. Geoforum 61:122-134. https://doi.org/10.1016/j.geoforum.2015.03.004

Larigauderie, A., and H. A. Mooney. 2010. The Intergovernmental Science-Policy Platform on Biodiversity and Ecosystem Services: moving a step closer to an IPCC-like mechanism for biodiversity. Current Opinion in Environmental Sustainability 2(1-2):9-14. https://doi.org/10.1016/j.cosust.2010.02.006

Larigauderie, A., M. Stenseke, and R. T. Watson. 2016. Biodiversity assessments: IPBES reaches out to social scientists. Nature 532(7599):313. https://doi.org/10.1038/532313c

Liu, J., V. Hull, M. Batistella, R. DeFries, T. Dietz, F. Fu, T. W. Hertel, R. C. Izaurralde, E. F. Lambin, S. Li, L. A. Martinelli, W. J. McConnell, E. F. Moran, R. Naylor, Z. Ouyang, K. R. Polenske, A. Reenberg, G. de Miranda Rocha, C. S. Simmons, P. H. Verburg, P. M. Vitousek, F. Zhang, and C. Zhu. 2013. Framing sustainability in a telecoupled world. Ecology and Society 18 (2):26. https://doi.org/10.5751/ES-05873-180226

Livoreil, B., I. Geijzendorffer, A. S. Pullin, S. Schindler, M. Vandewalle, and C. Nesshöver. 2016. Biodiversity knowledge synthesis at the European scale: actors and steps. Biodiversity and Conservation 25:1269-1284. https://doi.org/10.1007/s10531-016-1143-5

Luederitz, C., D. J. Abson, R. Audet, and D. J. Lang. 2017. Many pathways toward sustainability: not conflict but co-learning between transition narratives. Sustainability Science 12 (3):393-407. https://doi.org/10.1007/s11625-016-0414-0

Lundquist, C. J., H. M. Pereira, J. R. M. Alkemade, E. den Belder, S. Carvalho Ribeiro, K. Davies, A. Greenaway, S. I. S. E. KarlssonVinkhuyzen, H. Kim, T. Lazarova, L. Pereira, G. Peterson, F. Ravera, T. van den Brink, A. Argumedo, C. Arida, D. Armenteras, A.-G. Ausseil, B. Baptiste, J. Belanger, K. Bingham, A. BowdenKerby, M. Cao, J. Nettleton-Carino, P. A. Van Damme, R. Devivo, F. Dickson, J. P. Dushimumuremyi, S. Ferrier, A. Flores-Diaz, M. Foley, J. Garcia Marquez, P. Giraldo-Perez, S. Greenhalgh, D. J. Hamilton, P. Hardison, G. Hicks, K. Hughey, R. KahuiMcConnell, G. Wangechi Karuri-Sebina, M. de Kock, P. Leadley, F. Lemaitre, E. Maltseva, C. A. de Mattos Scaramuzza, M. Metwaly, W. Nelson, H. Ngo, C. Neumann, C. Norrie, J. Perry, R. Quintana, V. E. Rodriguez Osuna, R. Rohrl, J. Seager, H. Sharpe, T. Shortland, P. Shulbaeva, U. Rashid Sumaila, Y. Takahashi, T. Titeux, S. Tiwari, C. Trisos, A. Ursache, A. Wheatley, D. Wilson, S. Wood, E. van Wyk, T. X. Yue, and D. Zulfikar. 2017. Visions for nature and nature's contributions to people for the 21 st century. NIWA Science and Technology Series Number 83. The National Institute of Water \& Atmospheric Research Limited, Auckland, New Zealand.

Millennium Ecosystem Assessment (MA). 2005. Millennium Ecosystem Assessment: Synthesis report. Island Press, Washington, D.C., USA.

Mollinga, P. P. 2010. Boundary work and the complexity of natural resources management. Crop Science 50:S1-S9. https:// doi.org/10.2135/cropsci2009.10.0570

Nakićenović, N., J. Alcamo, G. Davis, B. de Vries, J. Fenhann, S. Gaffin, K. Gregory, A. Grübler, T. Y. Jung, T. Kram, E. Emilio la Rovere, L. Michaelis, S. Mori, T. Morita, W. Pepper, H. Pitcher,
L. Price, K. Riahi, A. Roehrl, H.-H. Rogner, A. Sankovski, M. E. Schlesinger, P. R. Shukla, S. Smith, R. J. Swart, S. van Rooyen, N. Victor, and Z. Dadi. 2000. Special report on emissions scenarios. Cambridge University Press, Cambridge, UK.

O'Neill, B. C., E. Kriegler, K. L. Ebi, E. Kemp-Benedict, K. Riahi, D. S. Rothman, B. J. van Ruijven, D. P. van Vuuren, J. Birkmann, K. Kok, M. Levy, and W. Solecki. 2017. The roads ahead: narratives for shared socioeconomic pathways describing world futures in the 21 st century. Global Environmental Change 42:169-180. https://doi.org/10.1016/j.gloenvcha.2015.01.004

Oberlack, C., L. Tejada, P. Messerli, S. Rist, and M. Giger. 2016. Sustainable livelihoods in the global land rush? Archetypes of livelihood vulnerability and sustainability potentials. Global Environmental Change 41:153-171. https://doi.org/10.1016/j. gloenvcha.2016.10.001

Oberlack, C., D. Sietz, E. Bürgi Bonanomi, A. De Bremond, J. Dell'Angelo, K. Eisenack, E. C. Ellis, G. Epstein, M. Giger, A. Heinimann, C. Kimmich, M. T. J. Kok, D. Manuel-Navarrete, P. Messerli, P. Meyfroidt, T. Václavík, and S. Villamayor-Tomás. 2019. Archetype analysis in sustainability research: meanings, motivations, and evidence-based policy making. Ecology and Society 24(2):26. https://doi.org/10.5751/ES-10747-240226

Ostrom, E. E. 2009. A general framework for analyzing sustainability of social-ecological systems. Science 325 (5939):419-422. https://doi.org/10.1126/science.1172133

Oteros-Rozas, E., B. Martín-López, T. Daw, E. L. Bohensky, J. Butler, R. Hill, J. Martin-Ortega, A. Quinlan, F. Ravera, I. RuizMallén, M. Thyresson, J. Mistry, I. Palomo, G. D. Peterson, T. Plieninger, K. A. Waylen, D. Beach, I. Bohnet, M. Hamann, J. Hanspach, K. Hubacek, S. Lavorel, and S. Vilardy. 2015. Participatory scenario planning in place-based social-ecological research: insights and experiences from 23 case studies. Ecology and Society 20(4):32. https://doi.org/10.5751/es-07985-200432

Pedde, S., K. Kok, K. Hölscher, C. Oberlack, P. A. Harrison and R. Leemans. 2019. Archetyping shared socioeconomic pathways across scales: an application to Central Asia and European case studies. Ecology and Society in press.

Pereira, H. M., P. W. Leadley, V. Proença, R. Alkemade, J. P. W. Scharlemann, J. F. Fernandez-Manjarrés, M. B. Araújo, P. Balvanera, R. Biggs, W. W. L. Cheung, L. Chini, H. D. Cooper, E. L. Gilman, S. Guénette, G. C. Hurtt, H. P. Huntington, G. M. Mace, T. Oberdorff, C. Revenga, P. Rodrigues, R. J. Scholes, U. R. Sumaila, and M. Walpole. 2010. Scenarios for global biodiversity in the 21st century. Science 330(6010):1496-1501. https://doi.org/10.1126/science.1196624

Pereira, L., N. Sitas, F. Ravera, A. Jimenez-Aceituno, and A. Merrie. 2019. Building capacities for transformative change towards sustainability: imagination in intergovernmental sciencepolicy scenario processes. Elementa in press.

Peterson, G. D., G. S. Cumming, and S. R. Carpenter. 2003. Scenario planning: a tool for conservation in an uncertain world. Conservation Biology 17(2):358-366. https://doi.org/10.1046/ j.1523-1739.2003.01491.X

Posner, S. M., E. McKenzie, and T. H. Ricketts. 2016. Policy impacts of ecosystem services knowledge. Proceedings of the 
National Academy of Sciences of the United States of America 113(7):1760-1765. https://doi.org/10.1073/pnas.1502452113

Raskin, P., T. Banuri, G. Gallopin, P. Gutman, A. Hammond, R. Kates, and R. Swart. 2002. Great transition: the promise and lure of the times ahead. A report of the Global Scenario Group. SEI PoleStar Series Report no. 10. Stockholm Environment Institute, Boston, Massachusetts, USA.

Richards, D. R., P. H. Warren, L. Maltby, and H. L. Moggridge. 2017. Awareness of greater numbers of ecosystem services affects preferences for floodplain management. Ecosystem Services 24:138-146. https://doi.org/10.1016/j.ecoser.2017.02.001

Rosa, I. M. D., H. M. Pereira, S. Ferrier, R. Alkemade, L. A. Acosta, H. R. Akcakaya, E. Den Belder, A. M. Fazel, S. Fujimori, M. Harfoot, K. A. Harhash, P. A. Harrison, J. Hauck, R. J. J. Hendriks, G. Hernández, W. Jetz, S. I. Karlsson-Vinkhuyzen, H. Kim, N. King, M. T. J. Kok, G. O. Kolomytsev, T. Lazarova, P. Leadley, C. J. Lundquist, J. García Márquez, C. Meyer, L. M. Navarro, C. Nesshöver, H. T. Ngo, K. N. Ninan, M. G. Palomo, L. M. Pereira, G. D. Peterson, R. Pichs, A. Popp, A. Purvis, F. Ravera, C. Rondinini, J. Sathyapalan, A. M. Schipper, R. Seppelt, J. Settele, N. Sitas, and D. Van Vuuren. 2017. Multiscale scenarios for nature futures. Nature Ecology and Evolution 1(10):1416-1419. https://doi.org/10.1038/s41559-017-0273-9

Sietz, D., U. Frey, M. Roggero, Y. Gong, N. Magliocca, R. Tan, P. Janssen, T. Václavík. 2019. Archetype analysis in sustainability research: methodological portfolio and analytical frontiers. Ecology and Society 24(3):34. https://doi.org/10.5751/ES-11103-240334

Sietz, D., M. K. B. Lüdeke, and C. Walther. 2011. Categorisation of typical vulnerability patterns in global drylands. Global Environmental Change 21(2):431-440. https://doi.org/10.1016/j. gloenvcha.2010.11.005

Sietz, D., J. C. Ordoñez, M. T. J. Kok, P. Janssen, H. B. M. Hilderink, P. Tittonell, and H. Van Dijk. 2017. Nested archetypes of vulnerability in African drylands: Where lies potential for sustainable agricultural intensification. Environmental Research Letters 12(9). https://doi.org/10.1088/1748-9326/aa768b

Sietz, D., B. Untied, O. Walkenhorst, M. K. B. Lüdeke, G. Mertins, G. Petschel-Held, and H. J. Schellnhuber. 2006. Smallholder agriculture in northeast Brazil: assessing heterogeneous human-environmental dynamics. Regional Environmental Change 6(3):132-146. https://doi.org/10.1007/ s10113-005-0010-9

Steffen, W., K. Richardson, J. Rockström, S. E. Cornell, I. Fetzer, E. M. Bennett, R. Biggs, S. R. Carpenter, W. de Vries, C. A. de Wit, C. Folke, D. Gerten, J. Heinke, G. M. Mace, L. M. Persson, V. Ramanathan, B. Reyers, S. Sorlin, and S. Sörlin. 2015. Planetary boundaries: guiding human development on a changing planet. Science 347(6223):1259855. https://doi. org/10.1126/science.1259855

Sterner, T., E. B. Barbier, I. Bateman, I. van den Bijgaart, A.-S. Crépin, O. Edenhofer, C. Fischer, W. Habla, J. Hassler, O. Johansson-Stenman, A. Lange, S. Polasky, J. Rockström, H. G. Smith, W. Steffen, G. Wagner, J. E. Wilen, F. Alpízar, C. Azar, D. Carless, C. Chávez, J. Coria, G. Engström, S. C. Jagers, G. Köhlin, Å. Löfgren, H. Pleijel, and A. Robinson. 2019. Policy design for the Anthropocene. Nature Sustainability 2(1):14-21. https://doi. org/10.1038/s41893-018-0194-x
United Nations Environment Programme (UNEP). 2007. Global Environment Outlook 4. UNEP, Nairobi, Kenya.

United Nations Environment Programme (UNEP). 2016. GEO-6 Regional Assessment for Africa. UNEP, Nairobi, Kenya

United Nations Environment Programme (UNEP). 2019. Global Environment Outlook 6. UNEP, Nairobi, Kenya.

United Nations General Assembly. 2015. Transforming our world: the 2030 Agenda for Sustainable Development, 21 October 2015, A/RES/70/1. UN General Assembly, New York, New York, USA.

Václavík, T., S. Lautenbach, T. Kuemmerle, and R. Seppelt. 2013. Mapping global land system archetypes. Global Environmental Change 23(6):1637-1647. https://doi.org/10.1016/j.gloenvcha.2013.09.004

van Vuuren, D. P., M. T. J. Kok, B. Girod, P. L. Lucas, and B. de Vries. 2012. Scenarios in global environmental assessments: key characteristics and lessons for future use. Global Environmental Change 22(4):884-895. https://doi.org/10.1016/j.gloenvcha.2012.06.001

Verburg, P. H., J. A. Dearing, J. G. Dyke, S. van der Leeuw, S. Seitzinger, W. Steffen, and J. Syvitski. 2016. Methods and approaches to modelling the Anthropocene. Global Environmental Change 39:328-340. https://doi.org/10.1016/j.gloenvcha.2015.08.007

Vidal Merino, M., D. Sietz, F. Jost, and U. Berger. 2019. Archetypes of climate vulnerability: a mixed-method approach applied in the Peruvian Andes. Climate and Development 11 (5):418-434. https://doi.org/10.1080/17565529.2018.1442804

Watson, R. T. 2012. The science-policy interface: the role of scientific assessments-UK National Ecosystem Assessment. Proceedings of the Royal Society A: Mathematical, Physical and Engineering Sciences 468(2147):3265-3281. https://doi.org/10.1098/ rspa.2012.0163

Waylen, K. A., and J. Young. 2014. Expectations and experiences of diverse forms of knowledge use: the case of the UK national ecosystem assessment. Environment and Planning C: Government and Policy 32(2):229-246. https://doi.org/10.1068/c1327j

White, D. D., A. Wutich, K. L. Larson, P. Gober, T. Lant, and C. Senneville. 2010. Credibility, salience, and legitimacy of boundary objects: water managers' assessment of a simulation model in an immersive decision theater. Science and Public Policy 37 (3):219-232. https://doi.org/10.3152/030234210X497726

World Wide Fund for Nature and African Development Bank (WWF-AfDB). 2015. African ecological futures report 2015. WWF, Gland, Switzerland, and AfDB, Nairobi, Kenya.

Young, J. C., K. A. Waylen, S. Sarkki, S. Albon, I. Bainbridge, E. Balian, J. Davidson, D. Edwards, R. Fairley, C. Margerison, D. McCracken, R. Owen, C. P. Quine, C. Stewart-Roper, D. Thompson, R. Tinch, S. van den Hove, and A. Watt. 2014. Improving the science-policy dialogue to meet the challenges of biodiversity conservation: having conversations rather than talking at one-another. Biodiversity and Conservation 23 (2):387-404. https://doi.org/10.1007/s10531-013-0607-0

Zurek, M. B., and T. Henrichs. 2007. Linking scenarios across geographical scales in international environmental assessments. Technological Forecasting and Social Change 74(8):1282-1295. https://doi.org/10.1016/j.techfore.2006.11.005 


\section{Appendix 1: Elaboration of methods}

\section{A. Meeting notes from IPBES workshops}

These included notes from: (1) First workshop on scenarios and modelling in support of IPBES assessments which included coordinating lead authors and IPBES Fellows from the scenario chapters of the regional assessments and selected experts from other IPBES assessments, hosted by the IPBES Technical Support Unit for Scenarios and Models, Bilthoven, the Netherlands, January 2016, (2) Second workshop on scenarios and modelling in support of IPBES assessments which included coordinating lead authors and IPBES Fellows from the scenario chapters of the regional assessments and selected chapters of the global assessment, hosted by the Institute for Global Environmental Strategies in Japan, and co-organized with the Expert Group and Technical Support Unit on Scenarios and Modelling, Shonan Village, Japan, November 2016, (3) First and second meetings of the respective regional assessments (Summer 2015, Autumn 2016) (IPBES 2018a), and (4) associated key meetings during the drafting of the chapter texts.

\section{B. Survey}

The survey was designed using Google forms and was sent out electronically on 19 December 2017 to 43 experts, who had 2 months to complete the survey. The survey was also sent out attached to an email in case respondents did not have access to Google. The survey was anonymous, although, given the nature of the purposeful sampling and details of the respondent profiles, some details requested would enable the identity of the respondent to be known to the research team. Nevertheless, no sensitive information was requested nor presented among the findings, and there was informed consent from all participants and confidentiality was maintained. The IPBES secretariat was contacted prior to the commencement of the analysis to ensure there was no conflict of interest. At the time of the publication of this paper, the IPBES Regional assessments had been finalised and accepted at the IPBES-6 Plenary; however the global assessment was still ongoing and thus many results are not permitted to be presented or discussed in this paper. We provide the full version of the survey below. 


\section{IPBES Scenario Archetype survey}

Thank you in advance for taking the time to complete the following questions!

This survey aims to contribute to a special issue on "Archetype analysis in sustainability research" in the journal Ecology and Society. A link to the focus and scope of the special issue can be found here:

https://www.ecologyandsociety.org/issues/view.php?sf=133

The outcomes of this survey will assist with a reflection on the understanding and use of the ways in which scenario archetype-based approaches have been used across the IPBES regional and global assessments and will be combined with a thematic assessment of the completed chapters. The questions focus on what the aims of applying a scenario archetype approach are, as well as the strengths and challenges that emerged during the process of using them in the IPBES assessment. We focus solely on the application of the scenario archetype approach within the IPBES assessments and the results will not include any of the results drafted during the assessment.

The survey will be sent predominantly to Chapter 5 authors of the IPBES regional assessments who were involved in the scenario archetype analysis, together with those authors involved in scenario archetype assessments in the IPBES global assessment as well as those who indicated they would be interested in being involved.

If you have any questions, please contact either [lead authors names]

\section{Section A: Background information}

1. Nationality:

2. Academic background:

a. Natural science

b. Social science

c. Humanities

d. Interdisciplinary

e. Other [...]

3. What type of institution are you based at?
a. Academic (e.g. university)
b. Research institution (e.g. science council or advisory body)
c. NGO
d. Government department
e. Other [...] 
4. Which assessment(s) are you part of (please select all that apply)

\begin{tabular}{|c|c|c|c|}
\hline $\begin{array}{l}\text { Type of Assessment/ } \\
\text { Group }\end{array}$ & Yes/No & $\begin{array}{l}\text { Chapter/ Type of } \\
\text { group }\end{array}$ & $\begin{array}{l}\text { Role (CLA, LA, } \\
\ldots \text { ) }\end{array}$ \\
\hline \multicolumn{4}{|l|}{$\begin{array}{l}\text { Regional Assessment: } \\
\text { Africa } \\
\text { Americas } \\
\text { Europe and Central } \\
\text { Asia } \\
\text { Asia Pacific }\end{array}$} \\
\hline \multicolumn{4}{|l|}{$\begin{array}{l}\text { Regional Assessments' } \\
\text { SPMs }\end{array}$} \\
\hline \multicolumn{4}{|l|}{ Global Assessment } \\
\hline \multicolumn{4}{|l|}{ Expert group } \\
\hline \multicolumn{4}{|l|}{ Technical Support Unit } \\
\hline Other & & & \\
\hline
\end{tabular}

5. How many years of experience in the field of scenarios do you have?
a. $1-5$
b. $6-10$
c. $11-20$
d. 21 and more

6. Did you use the scenario archetypes approach before your IPBES involvement?

a. Yes (please elaborate on your experience)

b. No

\section{Section B: Use of Scenario archetypes in IPBES assessments}

1. To your knowledge, how did you come to use scenario archetypes in your IPBES work? (e.g. I was told to, we had a meeting and decided this was a good way forward, I suggested it....)

2. To your knowledge, why where scenarios archetypes used for your IPBES work, i.e. what was the purpose of applying the scenario archetype approach and what questions were you trying to answer or assess with them?

3. Which scenario archetypes did you use in your work? (e.g. we created our own archetypes, we used existing ones, ...) 
4. Please describe your role, i.e. how you contributed to the work with scenario archetypes in the context of the assessment work. (If you took part in multiple assessments/groups, please describe each of your roles separately.)

5. According to your understanding, what does the "scenario archetypes approach" mean in the context of your IPBES-related work?

6. Were there any further scenario archetype analyses you wanted to do in your IPBES assessment?

a. If yes, please elaborate

b. If yes, why didn't you do it? (ran out of time, lack of expertise, ran out of space, ...)

7. Where there any alternative analysis approaches (not an archetype-based approach) that you wanted to apply?

8. How do you think using scenario archetypes can help in decision-making processes?

In the following questions, please list the top three points.

9. What are/were the strengths of using scenario archetypes in IPBES?

10. What are/were the weaknesses/barriers with using scenario archetypes in IPBES?

11. Were there any specific challenges linked to the scenario archetype assessment that came up in relation to*:

\begin{tabular}{llll}
\hline \hline & $\begin{array}{l}\text { Yes, } \\
\text { specifically: }\end{array}$ & No & $\begin{array}{l}\text { I don't } \\
\text { know }\end{array}$ \\
\hline
\end{tabular}

Issues of scale (e.g. temporal, spatial, cross-

scale suitability, regional relevance of global

archetypes, ...)

Policy relevance/coherence

Uncertainty

The level of generalization

Classification

Other

* This list of challenges came out of those challenges captured in meeting notes from discussions at the two key workshops in the Netherlands and Japan.

12. Beyond your IPBES work, what are some of the key gaps in current scenario archetype research?

13. What are some of the research frontiers in terms of scenario archetype analyses? 


\section{Appendix 2: Respondents' profile}

A total of 30 respondents completed the online survey (70\% response rate). The respondents covered all four of the IPBES regional assessments as well as the global assessment (Figure 1). The most represented regional assessment was Asia-Pacific, followed by Europe and Central Asia, Africa and Americas (See Figure 1). In addition to a specific regional assessment, some respondents contributed to other IPBES assessments and groups in parallel, e.g. the global assessment, the Scenarios and Models Thematic Assessment, the Expert Group on Scenarios and Models or the Technical Support Unit on Scenarios and Models. Multiple contributions were possible, therefore the counts of experts in individual groups do add up to more than $\mathrm{n}=30$.

Nearly half of respondents identified themselves as having natural science background (47\%), followed by interdisciplinary background (40\%), social science (7\%) and humanities (3\%). The vast majority of respondents were primarily based at academic or research institutions $(87 \%)$.

Most of the respondents indicated that they have experience of working within the sciencepolicy interface by virtue of being selected as experts for the assessment by their national focal points and have experience in policy as well as working closely with end-users in applied research. Six respondents are engaged directly in policy and decision-making processes.

Most of the respondents were fairly new to the field of using scenario applications, with 57\% having 1-5 years of experience in the scenario field, $23 \%$ with 6-10 years, $7 \%$ with 11-20 years and 10\% having more than 21 years of experience. At the same time, $73 \%$ of respondents had not used a scenario archetype approach before their work on the IPBES assessments. Of those that had previously used scenario archetypes, respondents indicated that scenario archetypes had been used for example in national ecosystem assessments, to translocate scenarios from a regional action project to a local case study, to compare scenarios across case studies using specific archetypes, or to classify scenarios based on worldviews and cultural theory. 
Figure A2.1: Number of respondents according to a) region of origin, b) background, c) sector, d) number of years of expertise $(n=30)$.

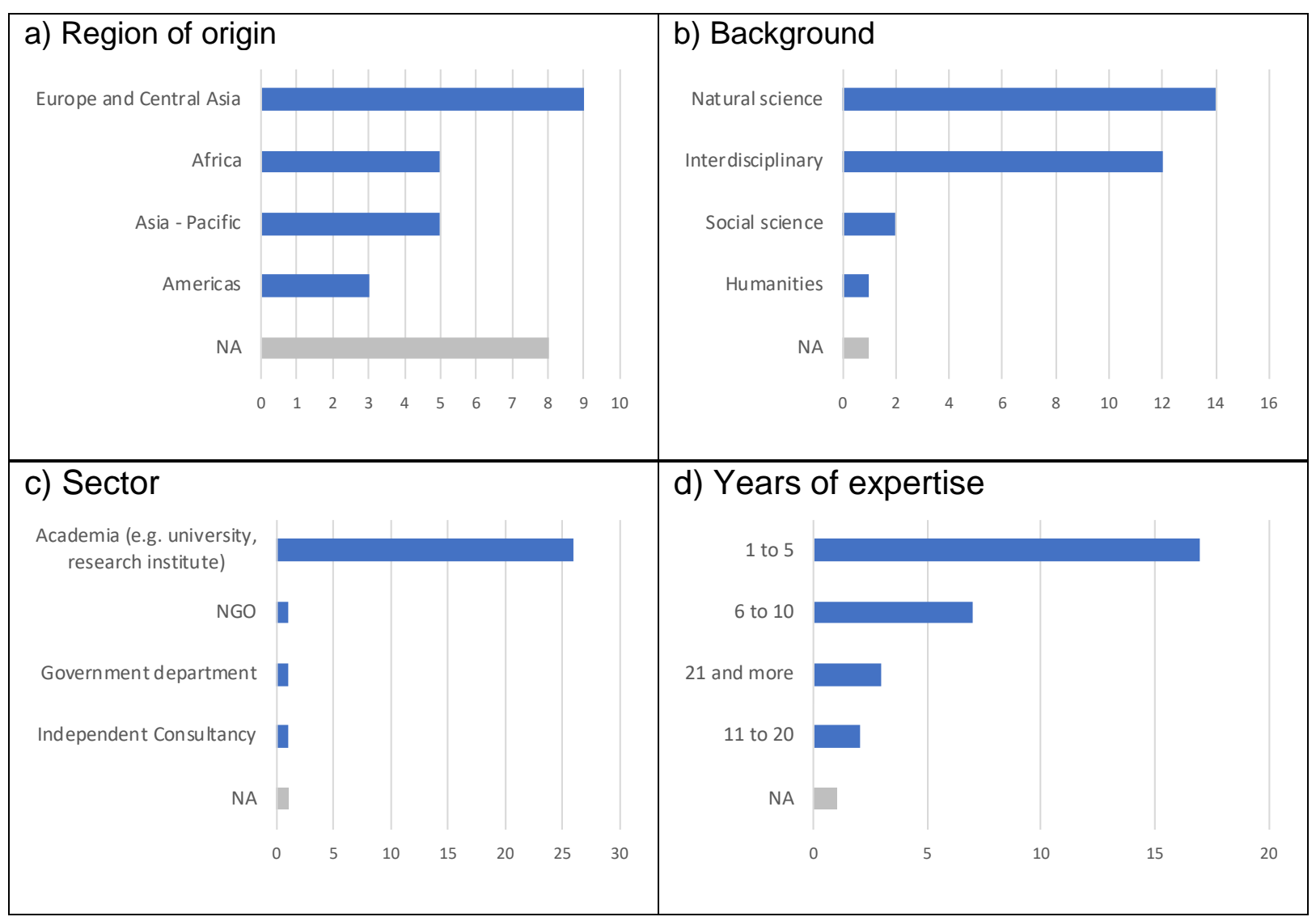




\section{Appendix 3: Details of the regional approaches for scenario archetype assessments}

Each of the IPBES regional assessments analysed the selected archetypes differently and to various extents (Biggs et al. 2018, Gundimeda et al. 2018, Harrison et al. 2018, Klatt et al. 2018). For instance, both the African and Europe and Central Asia assessments adjusted the global archetypes to create more regionally-specific versions, based on information from the respective regional reviews. Subsequently, both regional assessments qualitatively or semiquantitatively assessed plausible trends in driving forces, impacts on biodiversity, ecosystem services and human well-being, as well as the likelihood of reaching various sustainability related goals for each archetype, along with these well as policy options and pathways related to them (Biggs et al. 2018, Harrison et al. 2018). The African assessment formulated the regional archetypes based on 26 scenarios taken from a selection of six "core studies" (Biggs et al. 2018), while the Europe and Central Asia and Asia-Pacific assessments categorized all reviewed studies into the archetypes, with the Europe and Central Asia assessment subsequently using the archetypes to formulate their regional versions (Harrison et al. 2018, Gundimeda et al. 2018). In contrast, the Americas regional assessment used scenario archetypes as a general lens for discussing the results of regional assessments (Klatt et al. 2018).

Most regional assessments except for Asia-Pacific decided to omit the "Breakdown" archetype (Table A3.1) as it assumes a large-scale societal collapse and does not provide information on constructive pathways for decision makers (Klatt et al. 2018). Unlike other regional assessments, the Europe and Central Asia regional assessment included an "Inequality" archetype (Harrison et al. 2018, Harrison et al. 2019) which was added to reflect "the growing importance of this archetype in the scenario literature" (e.g. Kok and Pedde 2016, Kok et al. 2019, O'Neill et al. 2017). The Europe and Central Asia Inequality archetype assumes increasing economic, political and social inequalities, fragmentation and tensions both across and within countries, and is characterized by power becoming more concentrated in a relatively small political and business elite across the globe. Furthermore, the Europe and Central Asia regional assessment omitted the Reformed Markets archetype as, at the regional level, it was mostly synonymous with a change to more sustainable policies, and therefore fell within the Global Sustainability Development archetype at the Europe and Central Asia scale (Table A3.1) (Harrison et al. 2018).

In some of the regional assessments (notably the Europe and Central Asia assessment and the Africa assessment), the scenario archetypes also served as a means to integrate insights from different parts of the chapter; for example, in the Europe and Central Asia assessment, the archetypes were used as storylines connecting and synthesizing information from three reviews: a review of potential future trends in indirect and direct drivers, a review of the impacts of drivers on nature, nature's contributions to people and good quality of life, as well as a review of specific action pathways towards sustainable development (Harrison et al. 2018, 2019). The Africa regional assessment used a similar approach to integrate insights within the scenario chapter, but also used the archetypes to link findings in the scenario chapter with those of the policy-focused chapter (i.e. Chapter 6 in the IPBES assessment, which focused on policy and governance options under each of the scenario archetypes) (Biggs et al. 2018). 
Table A3.1: Summary of scenario archetypes used in individual IPBES regional assessments and their correspondence to selected global scenario archetype studies. For details of the regional versions of the scenario archetypes, please see Biggs et al. 2018, Gundimeda et al. 2018, Harrison et al. 2018, 2019, Klatt et al. 2018)

\begin{tabular}{|c|c|c|c|c|c|c|c|c|c|}
\hline \multicolumn{2}{|c|}{$\begin{array}{l}\text { Archetype categorization } \\
\text { according to: }\end{array}$} & \multicolumn{8}{|c|}{ Scenario Archetypes } \\
\hline $\begin{array}{l}\text { Global } \\
\text { archetype }\end{array}$ & $\begin{array}{l}\text { Global } \\
\text { Scenario } \\
\text { Group } \\
\text { (Gallopin and } \\
\text { Rijsberman, } \\
\text { 1997); Hunt et } \\
\text { al. (2012) }\end{array}$ & Market Forces & $\begin{array}{l}\text { Policy } \\
\text { Reform }\end{array}$ & $\begin{array}{l}\text { New } \\
\text { Sustainability } \\
\text { Paradigm }\end{array}$ & $\begin{array}{l}\text { Eco- } \\
\text { communalism }\end{array}$ & $\begin{array}{l}\text { Fortress } \\
\text { World }\end{array}$ & Breakdown & $\begin{array}{l}\text { Muddling } \\
\text { through }\end{array}$ & - \\
\hline studies & $\begin{array}{l}\text { Van Vuuren et } \\
\text { al. (2012); } \\
\text { IPBES } \\
\text { Scenarios and } \\
\text { Models } \\
\text { (IPBES 2016) }\end{array}$ & $\begin{array}{l}\text { Economic } \\
\text { optimism }\end{array}$ & $\begin{array}{l}\text { Reformed } \\
\text { Markets }\end{array}$ & $\begin{array}{l}\text { Global } \\
\text { Sustainable } \\
\text { Development }\end{array}$ & $\begin{array}{l}\text { Regional } \\
\text { Sustainability }\end{array}$ & $\begin{array}{l}\text { Regional } \\
\text { Competition }\end{array}$ & - & $\begin{array}{l}\text { Business-as- } \\
\text { Usual }\end{array}$ & - \\
\hline \multirow{4}{*}{$\begin{array}{l}\text { IPBES } \\
\text { Regional } \\
\text { assessments }\end{array}$} & Africa & Market Forces & $\begin{array}{l}\text { Policy } \\
\text { Reform }\end{array}$ & $\begin{array}{l}\text { Regional } \\
\text { Sustainability }\end{array}$ & $\begin{array}{l}\text { Local } \\
\text { Sustainability }\end{array}$ & $\begin{array}{l}\text { Fortress } \\
\text { World }\end{array}$ & - & - & - \\
\hline & Americas & Market Forces & $\begin{array}{l}\text { Policy } \\
\text { Reform }\end{array}$ & Great Transition & & Fortress World & & - & - \\
\hline & Asia-Pacific & Market Forces & $\begin{array}{l}\text { Policy } \\
\text { Reform }\end{array}$ & $\begin{array}{l}\text { New } \\
\text { Sustainability } \\
\text { Paradigm }\end{array}$ & $\begin{array}{l}\text { Eco- } \\
\text { communalism }\end{array}$ & $\begin{array}{l}\text { Fortress } \\
\text { World }\end{array}$ & Breakdown & - & - \\
\hline & $\begin{array}{l}\text { Europe and } \\
\text { Central Asia }\end{array}$ & $\begin{array}{l}\text { Economic } \\
\text { Optimism }\end{array}$ & - & $\begin{array}{l}\text { Global } \\
\text { Sustainable } \\
\text { Development }\end{array}$ & $\begin{array}{l}\text { Regional } \\
\text { Sustainability }\end{array}$ & $\begin{array}{l}\text { Regional } \\
\text { Competition }\end{array}$ & - & $\begin{array}{l}\text { Business-as- } \\
\text { Usual }\end{array}$ & Inequality \\
\hline $\begin{array}{l}\text { IPBES Global } \\
\text { assessment } \dagger\end{array}$ & & $\begin{array}{l}\text { Economic } \\
\text { optimism }\end{array}$ & $\begin{array}{l}\text { Reformed } \\
\text { Markets }\end{array}$ & $\begin{array}{l}\text { Global } \\
\text { Sustainable } \\
\text { Development }\end{array}$ & $\begin{array}{l}\text { Regional } \\
\text { Sustainability }\end{array}$ & $\begin{array}{l}\text { Regional } \\
\text { Competition }\end{array}$ & - & $\begin{array}{l}\text { Business-as- } \\
\text { Usual }\end{array}$ & - \\
\hline
\end{tabular}




\section{Appendix 4: Details of adopting the scenario archetype approach on the IPBES science- policy interface}

\section{Decision process to apply scenario archetypes}

According to the survey respondents, the decision to apply scenario archetypes as a means of harmonization and synthesis across regional assessments was not in place from the very beginning of the regional assessment process, but was made only later, when individual regional assessments were already at various stages of development. The respondents reported that the original idea to use scenario archetypes emerged from individual IPBES experts involved in the regional assessments during the initial stages of compiling the assessments. Subsequently, potential use of scenario archetypes across all regional assessments was discussed at the level of assessment chairs, coordinating lead authors and other key experts involved in the chapters at a variety of face-to-face meetings. Specifically, the first workshop on scenarios and modelling (Bilthoven, January 2016) focused on sharing experiences to set up the chapter on scenarios, discussing the main aims of the chapters in view of the whole assessment, discussing ways to find relevant studies and to summarize the results from these studies in a structured way. Furthermore, a framework to summarize scenario studies into scenario archetypes was jointly developed, which was subsequently used and continuously updated during the drafting of the assessments. The progress of the scenario archetype analysis in the regional assessments was shared in the second workshop on scenarios and modelling (Shonan Village, November 2016).

\section{Reflections of process clarity, transparency and consensus}

The survey showed that the awareness of the process leading to the selection of scenario archetypes as the overarching approach for the IPBES regional assessments differed among participants, depending on the level of overview they had, e.g. based on their role in the assessments. Nevertheless, there was a general agreement that the approach matched the purpose and capacities of the IPBES assessments and the respondents were generally satisfied with the level of clarity, transparency and consensus in the process of adopting scenario archetypes as a unifying approach within the IPBES assessments.

In addition, the respondents indicated that several confusions emerged during the process, e.g. (a) the word "archetype" was not initially understood by some of the authors, and (b) in some cases, scenario archetypes as a classification tool for organizing scenario studies tended to be mixed up with "scenarios" in general. This led to difficulties in communication across chapters in some regional assessments, as well as the communication of the findings of the archetype analysis outside the regional assessments, which illustrates the importance of defining and clarifying key terms and concepts early on in assessment processes.

\section{Dismissed alternatives to the scenario archetype approach}

The respondents also listed several alternative approaches originally considered for scenario synthesis instead of scenario archetypes, such as organizing scenarios based on: (1) the themes they focused on for example, poverty, food, water, or impacts of climate change; (2) input 
variables or drivers (e.g. population, gross domestic product), and (3) scale or region to which they applied. For instance, the IPBES Land Degradation and Restoration chapter on scenarios (IPBES 3bi) (Brink et al. 2018) ultimately adopted a biodiversity and ecosystem service based thematic framework to scenario classification due to the relative paucity of global integrated scenarios of land degradation. Such approaches would, according to the respondents, enable the analysis of scenarios without clustering them into shared archetype narratives which can result in the loss of detail and contextual nuances from the underlying scenarios (see Section 3: Challenges). In addition, quantitative aggregation of the scenarios was suggested as an alternative approach, which was, however, hampered by the extreme differences between indicators employed by different scenarios to model the same drivers. 